\title{
Directly Observed Transmetalation from Boron to Rhodium. $\beta$-Aryl Elimination from $R h(I)$ Arylboronates and Diarylborinates
}

\author{
Pinjing Zhao, Christopher D. Incarvito and John F. Hartwig* \\ Department of Chemistry, Yale University, PO Box 208107, New Haven CT, 06520-8107 \\ Department of Chemistry, University of Illinois, 600 South Mathews Avenue, Urbana, Illinois 61801
}

\section{Supporting Information}

\section{Table of Contents}

General Experimental Procedure and Reagent Availability. $\quad$ S2

General Procedure for the Preparation of Isolable Tris(triethylphosphine) Rh(I) S3 Arylborinates (3a-d).

Generation $\left[\left(\mathrm{PEt}_{3}\right)_{3} \mathrm{RhOB}(\mathrm{OH})(o\right.$-anisyl) $]$ (3e) and in situ Characterization by NMR S5 Spectroscopy.

Preparation of $\left[\left(\mathrm{PEt}_{3}\right)_{2} \mathrm{RhOB}(2 \text {-mesityl })_{2}\right](6) . \quad S 6$

Preparation of $\left[\left(\mathrm{PEt}_{3}\right)_{3} \mathrm{RhOB}\left(2-\mathrm{mesityl}_{2}\right](\mathbf{7}) . \quad \mathrm{S} 6\right.$

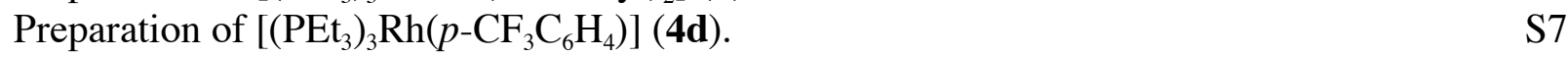

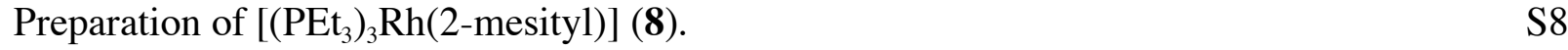

$\beta$-Aryl Eliminations of $\left[\left(\mathrm{PEt}_{3}\right)_{3} \mathrm{RhOB}(\mathrm{OH}) \mathrm{Ar}\right](\mathbf{3 a - e}) . \quad \mathrm{S} 8$

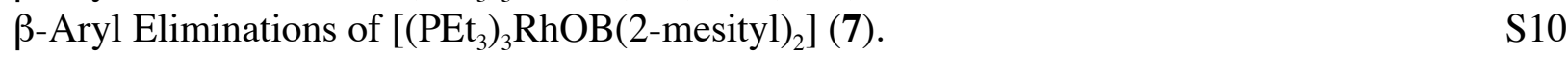

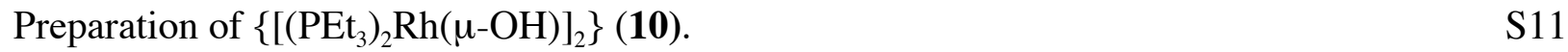

Reaction of $\left\{\left[\left(\mathrm{PEt}_{3}\right)_{2} \mathrm{Rh}(\mu-\mathrm{OH})\right]_{2}\right\}$ with $\mathrm{PhB}(\mathrm{OH})_{2}$ in the Presence of Added $\mathrm{PEt}_{3}$. $\quad$ S11

Reaction of $\left\{\left[\left(\mathrm{PEt}_{3}\right)_{2} \mathrm{Rh}(\mu-\mathrm{OH})\right]_{2}\right\}$ with $(\mathrm{Mes})_{2} \mathrm{~B}(\mathrm{OH})$ in the Presence of Added $\mathrm{PEt}_{3} . \quad \mathrm{S} 12$

Reaction of $\left\{\left(\mathrm{PEt}_{3}\right)_{2} \mathrm{Rh}\left[\mathrm{OC}(\mathrm{Ph})=\mathrm{CH}_{2}\right]\right\}$ with $\mathrm{PhB}(\mathrm{OH})_{2}$ in the Presence of Added $\mathrm{PEt}_{3} . \quad$ S12

Representative Procedure for the Kinetic Experiments Conducted on $\beta$-Aryl Eliminations $\quad S 12$ of $\left[\left(\mathrm{PEt}_{3}\right)_{3} \mathrm{RhOB}(\mathrm{OH})(p\right.$-tolyl $\left.)\right](\mathbf{3 b})$ in the Presence of Added $\mathrm{PEt}_{3}$.

Figure S1. Representative Kinetic Plot for $\beta$-Aryl Eliminations of $\left[\left(\mathrm{PEt}_{3}\right)_{3} \mathrm{RhOB}(\mathrm{OH})(p-\mathrm{S} 14\right.$ tolyl)] (3b) in the with Added $\mathrm{PEt}_{3}$.

Figure S2. Plot of $1 / k_{\text {obsd }}$ vs [ $\left[\mathrm{PEt}_{3}\right]$ for $\beta$-Aryl Elimination of Rhodium Complex $3 \mathbf{b}$ with $\mathrm{S} 15$ Added $\mathrm{PEt}_{3}$.

$\begin{array}{lr}\text { Table S1. Table of Data for Figure S2. } & \text { S15 }\end{array}$

$\begin{array}{ll}\text { References. } & \text { S16 }\end{array}$

$\begin{array}{ll}\text { Figure S3-S6. NMR Spectra of }\left[\left(\mathrm{PEt}_{3}\right)_{2} \mathrm{RhOB}(2 \text {-mesityl })_{2}\right](\mathbf{6}) . & \mathrm{S} 17\end{array}$

Experimental Procedure for the X-ray Diffraction of $\left[\left(\mathrm{PEt}_{3}\right)_{3} \mathrm{RhOB}(\mathrm{OH})(p\right.$-tolyl $\left.)\right](\mathbf{3 b}) . \quad$ S21

Figure S7. Intermolecular contacts in the solid-state structure of $\mathbf{3 b}$ S22

Table S2. Crystal Data and Structure Refinement for 3b. $\quad$ S23

Table S3. Atomic Coordinates $\left(\times 10^{4}\right)$ and Equivalent Isotropic Displacement Parameters S24 $\left(\AA^{2} \times 10^{3}\right)$ for $\mathbf{3 b}$.

Table S4. Bond Lengths and Angles for 3b. $\quad$ S26

Table S5. Anisotropic Displacement Parameters $\left(\AA^{2} \times 10^{3}\right)$ for $\mathbf{3 b} . \quad S 28$

Table S6. Hydrogen Coordinates $\left(x 0^{4}\right)$ and Isotropic Displacement Parameters $\left(\AA^{2} \mathrm{x}\right.$ S30 $10^{3}$ ) for $\mathbf{3 b}$.

Figure S8. ORTEP Diagram of $\mathbf{3 b}$. 
General. Unless noted otherwise, all manipulations were carried out under an inert atmosphere using a nitrogen-filled glovebox or standard Schlenk techniques. All glassware was oven-dried for approximately $1 \mathrm{~h}$ prior to use. THF, diethyl ether, toluene, benzene and pentane were degassed by purging with nitrogen for $45 \mathrm{~min}$ and dried with a solvent purification system using a $1 \mathrm{~m}$ column containing activated alumina. $\mathrm{C}_{6} \mathrm{D}_{6}, \mathrm{C}_{6} \mathrm{D}_{12}$ and THF- $d_{8}$ were dried over sodium benzophenone ketyl and vacuum transferred prior to use. ${ }^{1} \mathrm{H}$ NMR spectra were obtained on a $400-$ or $500-\mathrm{MHz}$ spectrometer, and chemical shifts were recorded relative to residual protiated solvent. ${ }^{13} \mathrm{C}$ NMR spectra were obtained at 100.6 or $125.8 \mathrm{MHz}$, and chemical shifts were recorded relative to the solvent resonance. Both ${ }^{1} \mathrm{H}$ NMR and ${ }^{13} \mathrm{C}$ NMR chemical shifts were reported in parts per million downfield from tetramethylsilane. ${ }^{31} \mathrm{P}$ NMR spectra were obtained at 161.9 MHz, and chemical shifts were reported in parts per million downfield of $85 \%$ $\mathrm{H}_{3} \mathrm{PO}_{4}(\delta=0) .{ }^{19} \mathrm{~F}$ NMR spectra were obtained at $376 \mathrm{MHz}$, and chemical shifts were recorded with a $\mathrm{C}_{6} \mathrm{~F}_{6}$ external standard $(\delta=-164.9) .{ }^{11} \mathrm{~B}$ NMR spectra were obtained at $160.4 \mathrm{MHz}$ or 96.3 $\mathrm{MHz}$, and chemical shifts were reported relative to $\mathrm{BF}_{3} \bullet \mathrm{OEt}_{2}$ as an external standard $(\delta=0)$.

$\mathrm{PEt}_{3}$, tetramethylsilane, dimesitylborinic acid (5), 2-mesitylmagnesium bromide and 1,3,5-trimethoxylbenzene were commercially available and used as received. Arylboronic acids 2a-e were commercially available and purified by recrystallization in water before being used.

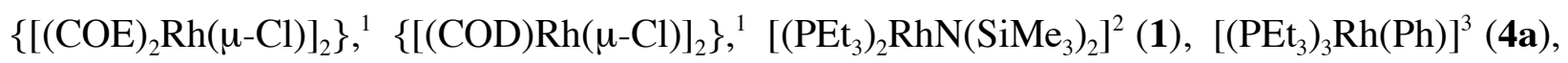
$\left[\left(\mathrm{PEt}_{3}\right)_{3} \mathrm{Rh}(p \text {-tolyl })\right]^{3} \quad(\mathbf{4 b}), \quad\left[\left(\mathrm{PEt}_{3}\right)_{3} \mathrm{Rh}(p \text {-anisyl })\right]^{3} \quad(\mathbf{4 c}), \quad\left[\left(\mathrm{PEt}_{3}\right)_{3} \mathrm{Rh}(o \text {-anisyl })\right]^{3} \quad(\mathbf{4 e})$, $\left\{[(\text { mesityl }) \mathrm{B}=\mathrm{O}]_{3}\right\}^{4}(\mathbf{9}), \quad\left\{[(\mathrm{COD}) \mathrm{Rh}(\mu-\mathrm{OH})]_{2}\right\}^{5}$ and $\left\{\left(\mathrm{PEt}_{3}\right)_{2} \mathrm{Rh}\left[\mathrm{OC}(\mathrm{Ph})=\mathrm{CH}_{2}\right]\right\}^{6}$ (11) were prepared according to literature procedures. Kinetic data for samples heated in an oil bath were obtained with a thermostated bath in which the temperature fluctuation was $\pm 0.1{ }^{\circ} \mathrm{C}$. The 
temperature of the samples of reactions monitored by NMR spectroscopy was measured with a thermocouple inserted through the instrument into a toluene solution in an NMR sample tube.

General Procedure for the Preparation of Isolable Tris(triethylphosphine) $R$ h(I) Arylborinates (3a-d). Into a $20 \mathrm{~mL}$ scintillation vial equipped with a magnetic stir bar was placed $\left(\mathrm{PEt}_{3}\right)_{2} \mathrm{RhN}\left(\mathrm{SiMe}_{3}\right)_{2}(200 \mathrm{mg}, 0.40 \mathrm{mmol}), \mathrm{PEt}_{3}(52 \mathrm{mg}, 0.44 \mathrm{mmol}, 1.1$ equiv), and THF (5 mL). The corresponding arylboronic acid ( $0.40 \mathrm{mmol}, 1.0$ equiv) was dissolved in THF (2 $\mathrm{mL}$ ) and added dropwise under stirring. An instant color change from dark purple to orange was observed. The solution was stirred at room temperature for 5-10 min until the rhodium silylamide was fully converted, as determined by ${ }^{31} \mathrm{P}$ NMR spectroscopy. The volatile materials were evaporated under reduced pressure, affording the crude rhodium boronate product as a precipitate. Further purification was achieved by crystallization from pentane/diethyl ether layering or tetramethylsilane/pentane layering at $-35^{\circ} \mathrm{C}$.

Preparation of $\left[\left(\mathbf{P E t}_{3}\right)_{3} \mathbf{R h O B}(\mathbf{O H})(\mathbf{P h})\right]$ (3a). The general procedure for the preparation of tris(triethylphosphine) rhodium(I) arylborinates, followed by crystallization from pentane/diethyl ether at $-35^{\circ} \mathrm{C}$, gave orange crystals of 3a (173 mg, 75\% yield). ${ }^{1} \mathrm{H}$ NMR (400 $\mathrm{MHz}, \mathrm{C}_{6} \mathrm{D}_{6}$; sample assignments for the proton signals are shown here and are analogous for the rest of the tris(phosphine) rhodium boronate complexes): $\delta 0.96-1.14\left(\mathrm{~m}, 27 \mathrm{H}, \mathrm{CH}_{3}\right.$ signals for $\mathrm{PEt}_{3}$ ligands), 1.18-1.32 (m, $6 \mathrm{H}, \mathrm{CH}_{2}$ signals for the trans $\mathrm{PEt}_{3}$ ligand), 1.55-1.65 (m, $12 \mathrm{H}, \mathrm{CH}_{2}$ signals for the cis $\mathrm{PEt}_{3}$ ligands), 4.75 (s, 1H, hydroxy), 7.35 (t, $\left.J=7.0 \mathrm{~Hz}, 1 \mathrm{H}\right), 7.47$ (d, J=7.4 Hz, 2H), $8.57\left(\mathrm{dd}, J_{1}=8.0 \mathrm{~Hz}, J_{2}=1.4 \mathrm{~Hz}, 2 \mathrm{H}\right) .{ }^{11} \mathrm{~B} \mathrm{NMR}(96.3 \mathrm{MHz}, \mathrm{THF}): \delta 25.6 .{ }^{13} \mathrm{C} \mathrm{NMR}(125.6$ MHz, THF- $\left.d_{8},-20{ }^{\circ} \mathrm{C}\right): \delta 9.0,9.5,16.8(\mathrm{t}, J=11.0 \mathrm{~Hz}), 21.4(\mathrm{~d}, J=25.7 \mathrm{~Hz}), 127.2,128.2,135.5$, 140.3 (broad). ${ }^{31} \mathrm{P}$ NMR (161.9 MHz, $\left.\mathrm{C}_{6} \mathrm{D}_{6}\right): \delta 20.4\left(\mathrm{dd}, J_{\mathrm{PRh}}=141 \mathrm{~Hz}, J_{\mathrm{PP}}=41 \mathrm{~Hz}\right), 37.9(\mathrm{dt}$, 
$J_{\mathrm{PRh}}=187 \mathrm{~Hz}, J_{\mathrm{PP}}=41 \mathrm{~Hz}$ ). Anal. Calcd for $\mathrm{C}_{24} \mathrm{H}_{51} \mathrm{BO}_{2} \mathrm{P}_{3} \mathrm{Rh}: \mathrm{C}, 49.85 ; \mathrm{H}, 8.89$. Found: C, 49.96; H, 9.06 .

Preparation of $\left[\left(\mathbf{P E t}_{3}\right)_{3} \mathbf{R h O B}(\mathbf{O H})(p\right.$-tolyl) $](3 \mathrm{~b})$. The general procedure for the preparation of tris(triethylphosphine) rhodium(I) arylborinates, followed by crystallization from pentane/diethyl ether at $-35{ }^{\circ} \mathrm{C}$, gave orange crystals of $\mathbf{3 b}$ (180 mg, $76 \%$ yield). ${ }^{1} \mathrm{H}$ NMR (400 $\left.\mathrm{MHz}, \mathrm{C}_{6} \mathrm{D}_{6}\right): \delta$ 0.98-1.16 (m, $\left.27 \mathrm{H}\right), 1.20-1.35(\mathrm{~m}, 6 \mathrm{H}), 1.55-1.65(\mathrm{~m}, 12 \mathrm{H}), 2.24(\mathrm{~s}, 3 \mathrm{H}$, tolyl $\mathrm{CH}_{3}$ signal), $4.71(\mathrm{~s}, 1 \mathrm{H}), 7.30(\mathrm{~d}, J=7.7 \mathrm{~Hz}, 2 \mathrm{H}), 8.51(\mathrm{~d}, J=7.7 \mathrm{~Hz}, 2 \mathrm{H}) .{ }^{11}$ B NMR $(160.4 \mathrm{MHz}$, THF- $d_{8}$ ): $\delta 25.0 .{ }^{13} \mathrm{C}$ NMR (100.6 MHz, THF- $\left.d_{8}\right): \delta$ 9.0, 9.4, 16.7 (t, $\left.J=11.2 \mathrm{~Hz}\right), 21.3(\mathrm{~d}, J=25.0$ $\mathrm{Hz}), 21.6,127.8,135.5,137.2,137.7$ (broad). ${ }^{31} \mathrm{P}$ NMR (161.9 MHz, $\left.\mathrm{C}_{6} \mathrm{D}_{6}\right): \delta 21.0$ (dd, $J_{\mathrm{PRh}}=140$ $\left.\mathrm{Hz}, J_{\mathrm{PP}}=41 \mathrm{~Hz}\right), 37.9\left(\mathrm{dt}, J_{\mathrm{PRh}}=166 \mathrm{~Hz}, J_{\mathrm{PP}}=41 \mathrm{~Hz}\right.$ ). Anal. Calcd for $\mathrm{C}_{25} \mathrm{H}_{53} \mathrm{BO}_{2} \mathrm{P}_{3} \mathrm{Rh}: \mathrm{C}, 50.69 ; \mathrm{H}$, 9.02. Found: C, 50.51; H, 9.15.

Preparation of $\left[\left(\mathrm{PEt}_{3}\right)_{3} \mathrm{RhOB}(\mathrm{OH})(p\right.$-anisyl $\left.)\right](3 \mathrm{c})$. The general procedure for the preparation of tris(triethylphosphine) rhodium(I) arylborinates, followed by crystallization from pentane/diethyl ether at $-35{ }^{\circ} \mathrm{C}$, gave orange crystals of $3 \mathrm{c}\left(163 \mathrm{mg}, 67 \%\right.$ yield). ${ }^{1} \mathrm{H}$ NMR (400 $\left.\mathrm{MHz}, \mathrm{C}_{6} \mathrm{D}_{6}\right): \delta 1.00-1.18(\mathrm{~m}, 27 \mathrm{H}), 1.22-1.35(\mathrm{~m}, 6 \mathrm{H}), 1.55-1.65(\mathrm{~m}, 12 \mathrm{H}), 3.37(\mathrm{~s}, 3 \mathrm{H}), 4.67$ (s, 1H), $7.08(\mathrm{~d}, J=8.4 \mathrm{~Hz}, 2 \mathrm{H}), 8.52(\mathrm{~d}, J=8.4 \mathrm{~Hz}, 2 \mathrm{H}) .{ }^{11}$ B NMR $\left(160.4 \mathrm{MHz}, \mathrm{THF}-d_{8}\right): \delta 23.2$. ${ }^{13} \mathrm{C}$ NMR (100.6 MHz, THF- $d_{8}$ ): $\delta$ 7.1, 7.6, 14.8 (t, $\left.J=11.0 \mathrm{~Hz}\right), 19.4$ (d, $\left.J=24.8 \mathrm{~Hz}\right), 52.9,110.5$, 130.7 (broad), 134.8, 158.8. ${ }^{31} \mathrm{P}$ NMR $\left(161.9 \mathrm{MHz}, \mathrm{C}_{6} \mathrm{D}_{6}\right): \delta 21.4\left(\mathrm{dd}, J_{\mathrm{PRh}}=139 \mathrm{~Hz}, J_{\mathrm{PP}}=41 \mathrm{~Hz}\right)$, $38.3\left(\mathrm{dt}, J_{\mathrm{PRh}}=166 \mathrm{~Hz}, J_{\mathrm{PP}}=41 \mathrm{~Hz}\right.$ ). Anal. Calcd for $\mathrm{C}_{25} \mathrm{H}_{53} \mathrm{BO}_{3} \mathrm{P}_{3} \mathrm{Rh}: \mathrm{C}, 49.36 ; \mathrm{H}, 8.78$. Found: C, 49.72; H, 9.01.

Preparation of $\left[\left(\mathrm{PEt}_{3}\right)_{3} \mathrm{RhOB}(\mathrm{OH})\left(4-\mathrm{CF}_{3} \mathrm{C}_{6} \mathrm{H}_{4}\right)\right](3 \mathrm{~d})$. The general procedure for the preparation of tris(triethylphosphine) rhodium(I) arylborinates, followed by crystallization from tetramethylsilane/pentane at $-35{ }^{\circ} \mathrm{C}$, gave orange crystals of $\mathbf{3 d}(116 \mathrm{mg}, 45 \%$ yield). The 
stability of this complex at room temperature was limited, and it was stored at $-35{ }^{\circ} \mathrm{C} .{ }^{1} \mathrm{H} \mathrm{NMR}$ (400 MHz, $\left.\mathrm{C}_{6} \mathrm{D}_{6}\right): \delta$ 0.92-1.14 (m, $\left.27 \mathrm{H}\right), 1.18-1.32(\mathrm{~m}, 6 \mathrm{H}), 1.50-1.60(\mathrm{~m}, 12 \mathrm{H}), 4.81(\mathrm{~s}, 1 \mathrm{H})$, $7.65(\mathrm{~d}, J=8.0 \mathrm{~Hz}, 2 \mathrm{H}), 8.47(\mathrm{~d}, J=8.0 \mathrm{~Hz}, 2 \mathrm{H}) .{ }^{11} \mathrm{~B} \mathrm{NMR}(96.3 \mathrm{MHz}, \mathrm{THF}): \delta 25.8 .{ }^{13} \mathrm{C}$ NMR $\left(125.6 \mathrm{MHz}, \mathrm{THF}-d_{8},-20{ }^{\circ} \mathrm{C}\right): \delta 9.0,9.5,16.8(\mathrm{t}, J=11.0 \mathrm{~Hz}), 21.4(\mathrm{~d}, J=25.7 \mathrm{~Hz}), 123.9,126.1$ (quartet, $J=271.4 \mathrm{~Hz}$ ), 129.9 (quartet, $J=18.7 \mathrm{~Hz}$ ), 135.8, 145.9 (broad). ${ }^{19} \mathrm{~F}$ NMR (376 MHz, $\left.\mathrm{C}_{6} \mathrm{D}_{6}\right): \delta-62.3 .{ }^{31} \mathrm{P}$ NMR $\left(161.9 \mathrm{MHz}, \mathrm{C}_{6} \mathrm{D}_{6}\right): \delta 21.0\left(\mathrm{dd}, J_{\mathrm{PRh}}=139 \mathrm{~Hz}, J_{\mathrm{PP}}=41 \mathrm{~Hz}\right), 38.3(\mathrm{dt}$, $J_{\mathrm{PRh}}=168 \mathrm{~Hz}, J_{\mathrm{PP}}=41 \mathrm{~Hz}$ ). Anal. Calcd for $\mathrm{C}_{25} \mathrm{H}_{50} \mathrm{BF}_{3} \mathrm{O}_{2} \mathrm{P}_{3} \mathrm{Rh}: \mathrm{C}, 46.46 ; \mathrm{H}, 7.80$. Found: C, 46.26; H, 7.99.

\section{Generation of $\left[\left(\mathrm{PEt}_{3}\right)_{3} \mathrm{RhOB}(\mathrm{OH})(o\right.$-anisyl)] (3e) and in situ Characterization by}

NMR Spectroscopy. Into a small vial equipped with a magnetic stir bar was placed $\left[\left(\mathrm{PEt}_{3}\right)_{2} \mathrm{Rh}(\mathrm{OH})\right]_{2}(35.6 \mathrm{mg}, 0.050 \mathrm{mmol}), \mathrm{PEt}_{3}(12.4 \mathrm{mg}, 2.1$ equiv, $0.105 \mathrm{mmol})$ and THF- $d_{8}$ $(0.40 \mathrm{~mL})$. The resulting solution was stirred briefly at room temperature before being transferred to a medium-walled NMR tube equipped with a screw cap and a Teflon seal. The sample was cooled to $-78{ }^{\circ} \mathrm{C}$. $o$-anisylboronic acid (2e, $15.2 \mathrm{mg}, 2.0$ equiv, $0.100 \mathrm{mmol}$ ) was dissolved in THF- $d_{8}(0.20 \mathrm{~mL})$ and syringed into the NMR tube at $-78{ }^{\circ} \mathrm{C}$ under a nitrogen flow. The mixture was allowed to sit at $-78{ }^{\circ} \mathrm{C}$ for 10 min before being mixed by shaking several times for less than $10 \mathrm{~s}$. A color change from light orange to red orange was observed, indicating conversion of the starting silylamido precursor. The NMR tube was then immediately placed in the cold NMR probe $\left(-40{ }^{\circ} \mathrm{C}\right)$, and the subsequent NMR characterization was carried out at low temperatures to avoid decomposition. ${ }^{1} \mathrm{H}$ NMR $\left(400 \mathrm{~Hz}, \mathrm{THF}-d_{8},-40{ }^{\circ} \mathrm{C}\right): \delta 0.98-1.16(\mathrm{~m}, 27 \mathrm{H})$, 1.20-1.34 (m, $6 \mathrm{H}), 1.55-1.65$ (m, $12 \mathrm{H}), 3.40$ (s, 3H), 4.67 (s, 1H), 6.67 (d, J=8.0 Hz, 1H), 7.16 (t, $J=7.2 \mathrm{~Hz}, 1 \mathrm{H}), 7.32(\mathrm{t}, J=7.2 \mathrm{~Hz}, 1 \mathrm{H}), 8.38(\mathrm{t}, J=6.0 \mathrm{~Hz}, 1 \mathrm{H}) .{ }^{11} \mathrm{~B}$ NMR $\left(96.3 \mathrm{MHz}, \mathrm{THF}-d_{8}\right)$ : $\delta$ 25.7. ${ }^{13} \mathrm{C}$ NMR $\left(125.6 \mathrm{MHz}, \mathrm{THF}-d_{8},-40{ }^{\circ} \mathrm{C}\right): \delta 9.2,9.6,17.0(\mathrm{t}, J=10.6 \mathrm{~Hz}), 21.5(\mathrm{~d}, J=24.0$ 
Hz), 55.1, 109.6, 120.8, 128.9 (broad), 129.8, 139.2, 164. ${ }^{31} \mathrm{P}$ NMR (161.9 MHz, THF- $d_{8},-40$

$\left.{ }^{\circ} \mathrm{C}\right): \delta 21.1\left(\mathrm{dd}, J_{\mathrm{PRh}}=143 \mathrm{~Hz}, J_{\mathrm{PP}}=42 \mathrm{~Hz}\right), 39.1\left(\mathrm{dt}, J_{\mathrm{PRh}}=169 \mathrm{~Hz}, J_{\mathrm{PP}}=42 \mathrm{~Hz}\right)$.

Preparation of $\left[\left(\mathbf{P E t}_{3}\right)_{2} \mathbf{R h O B}(2 \text {-mesityl })_{2}\right](6)$. Into a $20 \mathrm{~mL}$ scintillation vial equipped with a magnetic stir bar was placed $\left(\mathrm{PEt}_{3}\right)_{2} \mathrm{RhN}\left(\mathrm{SiMe}_{3}\right)_{2}(200 \mathrm{mg}, 0.40 \mathrm{mmol})$ and $\mathrm{THF}(5 \mathrm{~mL})$. Dimesitylborinic acid $(\mathbf{5}, 106 \mathrm{mg}, 0.40 \mathrm{mmol}, 1.0$ equiv) was dissolved in THF (2 mL) and added dropwise under stirring. An instant color change from dark purple to maroon was observed. The solution was then stirred at room temperature for less than 5 min to ensure full conversion and to avoid decomposition. The volatile materials were evaporated under reduced pressure, affording the crude product as a maroon precipitate. Further purification was achieved by crystallization from pentane at $-35^{\circ} \mathrm{C}$ to give 6 as maroon crystals (172 $\mathrm{mg}, 71 \%$ yield). The stability of this complex at room temperature was limited, and it was stored at $-35{ }^{\circ} \mathrm{C}$. Although the analytical data for most of the rhodium complexes in this work were acceptable, and the spectral data of this complex indicated similar purity, the thermal instability of this complex prevented obtaining suitable analytical data on this complex. NMR spectra are provided below to demonstrate purity (Figures S3-S6). ${ }^{1} \mathrm{H}$ NMR (400 MHz, THF- $d_{8}$,): $\delta 0.98-1.08\left(\mathrm{~m}, 18 \mathrm{H}, \mathrm{CH}_{3}\right.$ signals for the $\mathrm{PEt}_{3}$ ligands), 1.23-1.28 (m, 12H, $\mathrm{CH}_{2}$ signals for the $\mathrm{PEt}_{3}$ ligands), 2.11 (s, $6 \mathrm{H}$, para $\mathrm{CH}_{3}$ signal), 2.28 (s, $12 \mathrm{H}$, ortho $\mathrm{CH}_{3}$ signal), 6.61 (s, 4H, meta proton signal). ${ }^{11} \mathrm{~B}$ NMR (96.3 MHz, THF): $\delta 49.0 .{ }^{13} \mathrm{C}$ NMR (100.6 MHz, THF- $\left.d_{8}\right): \delta 10.1,19.0(\mathrm{t}, J=17.7 \mathrm{~Hz}), 22.7$, 25.1, 129.8, 129.6 (broad), 140.2, $146.0{ }^{31} \mathrm{P}$ NMR (161.9 MHz, THF- $\left.d_{8}\right): \delta 38.8$ (d, $\left.J=210 \mathrm{~Hz}\right)$.

Preparation of $\left[\left(\mathbf{P E t}_{3}\right)_{3} \mathbf{R h O B}(2-\text { mesityl })_{2}\right]$ (7). Into a $20 \mathrm{~mL}$ scintillation vial equipped with a magnetic stir bar was placed $\left(\mathrm{PEt}_{3}\right)_{2} \mathrm{RhN}\left(\mathrm{SiMe}_{3}\right)_{2}(200 \mathrm{mg}, 0.40 \mathrm{mmol}), \mathrm{PEt}_{3}(52 \mathrm{mg}, 0.44$ mmol, 1.1 equiv) and THF (5 mL). Dimesitylborinic acid (5, $106 \mathrm{mg}, 0.40 \mathrm{mmol}, 1.0$ equiv) was dissolved in THF (2 mL) and added dropwise under stirring. An instant color change from 
dark purple to orange was observed. The solution was then stirred at room temperature for 30 min until the rhodium silylamide was fully converted, as determined by ${ }^{31} \mathrm{P}$ NMR spectroscopy. The volatile materials were evaporated under reduced pressure, affording the crude product as an orange precipitate. Further purification was achieved by crystallization from pentane at $-35^{\circ} \mathrm{C}$ to give 7 as orange crystals $\left(237 \mathrm{mg}, 82 \%\right.$ yield). ${ }^{1} \mathrm{H}$ NMR $\left(400 \mathrm{MHz}, \mathrm{C}_{6} \mathrm{D}_{6}\right): \delta 0.92-1.02(\mathrm{~m}$, 27H), 1.24-1.38 (m, 6H), 1.42-1.55 (m, 12H), $2.30(\mathrm{~s}, 6 \mathrm{H}), 2.82\left(\right.$ broad s, 12H), $6.92(\mathrm{~s}, 4 \mathrm{H}) .{ }^{11} \mathrm{~B}$ NMR (96.3 MHz, THF): $\delta 41.1 .{ }^{13} \mathrm{C}$ NMR (125.8 MHz, THF- $\left.d_{8}\right): \delta 10.0,10.6,18.3(\mathrm{t}, J=10.5$ $\mathrm{Hz}$ ), 22.5, 23.3 (d, J=25.8 Hz), 25.0 (broad), 129.5, 136.0, 141.8 (broad), 148.7 (broad). ${ }^{31} \mathrm{P}$ NMR (161.9 MHz, THF- $\left.d_{8}\right): \delta 16.6\left(\mathrm{dd}, J_{\mathrm{PRh}}=143 \mathrm{~Hz}, J_{\mathrm{PP}}=45 \mathrm{~Hz}\right), 40.3\left(\mathrm{dt}, J_{\mathrm{PRh}}=172 \mathrm{~Hz}, J_{\mathrm{PP}}=45\right.$ Hz). Anal. Calcd for $\mathrm{C}_{36} \mathrm{H}_{67} \mathrm{BOP}_{3} \mathrm{Rh}$ : C, 59.84; H, 9.35. Found: C, 60.08; H, 9.38.

Preparation of $\left[\left(\mathbf{P E t}_{3}\right)_{3} \mathbf{R h}\left(p-\mathrm{CF}_{3} \mathbf{C}_{6} \mathbf{H}_{4}\right)\right]$ (4d). Into a $20 \mathrm{~mL}$ scintillation vial equipped with a magnetic stir bar was placed $\left(\mathrm{PEt}_{3}\right)_{2} \mathrm{RhN}\left(\mathrm{SiMe}_{3}\right)_{2}(200 \mathrm{mg}, 0.40 \mathrm{mmol})$ and $\mathrm{THF}(5 \mathrm{~mL})$. 4-trifluoromethylphenylboronic acid $(0.40 \mathrm{mmol}, 1.0$ equiv) was dissolved in THF (2 mL) and added dropwise under stirring. An instant color change from dark purple to orange was observed, indicating the formation of the corresponding arylboronate complex 3d. The solution was then stirred at room temperature for $12 \mathrm{~h}$ until $\mathbf{3 d}$ was fully converted, as determined by ${ }^{31} \mathrm{P}$ NMR spectroscopy. The volatile materials were evaporated under reduced pressure, affording the crude product as an orange precipitate. Further purification was achieved by crystallization from pentane at $-35{ }^{\circ} \mathrm{C}$ to give $\mathbf{4 d}$ as orange crystals ( $171 \mathrm{mg}, 71 \%$ yield). ${ }^{1} \mathrm{H}$ NMR (400 MHz, THF- $\left.d_{8}\right): \delta 0.98-1.07(\mathrm{~m}, 18 \mathrm{H}), 1.13-1.24(\mathrm{~m}, 12 \mathrm{H}), 1.28-1.42(\mathrm{~m}, 9 \mathrm{H}), 1.58-1.70(\mathrm{~m}, 6 \mathrm{H}), 6.94$ $(\mathrm{d}, 2 \mathrm{H}, J=7.7 \mathrm{~Hz}), 7.76(\mathrm{t}, 2 \mathrm{H}, J=6.0 \mathrm{~Hz}) .{ }^{13} \mathrm{C} \mathrm{NMR}\left(100.6 \mathrm{MHz}, \mathrm{THF}-d_{8}\right): \delta 10.2,10.8,19.5(\mathrm{t}$, $J=10.2 \mathrm{~Hz}$ ), 22.4 (d, $J=16.1 \mathrm{~Hz}), 121.8,123.6$ (quartet, $J=31.3 \mathrm{~Hz}$ ), 128.4 (quartet, $J=270.1 \mathrm{~Hz}$ ), $141.7,192.3\left(\mathrm{ddt}, J_{1}=77.0 \mathrm{~Hz}, J_{2}=27.9 \mathrm{~Hz}, J_{3}=17.1 \mathrm{~Hz}\right) .{ }^{19} \mathrm{~F}$ NMR $\left(376 \mathrm{MHz}, \mathrm{THF}-d_{8}\right): \delta-60.5$. 
${ }^{31} \mathrm{P}$ NMR $\left(161.9 \mathrm{MHz}, \mathrm{THF}-d_{8}\right): \delta 15.1\left(\mathrm{dd}, J_{\mathrm{PRh}}=156 \mathrm{~Hz}, J_{\mathrm{PP}}=36 \mathrm{~Hz}\right), 21.1\left(\mathrm{dt}, J_{\mathrm{PRh}}=115 \mathrm{~Hz}\right.$, $J_{\mathrm{PP}}=36 \mathrm{~Hz}$ ). Anal. Calcd for $\mathrm{C}_{25} \mathrm{H}_{49} \mathrm{~F}_{3} \mathrm{P}_{3} \mathrm{Rh}: \mathrm{C}, 49.84 ; \mathrm{H}, 8.20$. Found: C, 50.04; H, 8.28.

Preparation of $\left[\left(\mathbf{P E t}_{\mathbf{3}}\right)_{\mathbf{3}} \mathbf{R h}(\mathbf{2}-\mathrm{mesityl})\right]^{3} \mathbf{( 8 )}$. Into a $20 \mathrm{~mL}$ scintillation vial equipped with a magnetic stir bar was placed $\left[(\mathrm{COE})_{2} \mathrm{Rh}(\mu-\mathrm{Cl})\right]_{2}(200 \mathrm{mg}, 0.279 \mathrm{mmol})$ and $\mathrm{THF}(5 \mathrm{~mL})$. $\mathrm{PEt}_{3}(246 \mu \mathrm{L}, 2.11 \mathrm{mmol}, 6.05$ equiv) was added by syringe, and the solution was stirred for 5$10 \mathrm{~min}$ at room temperature. 2-Mesitylmagnesium bromide $(1.0 \mathrm{M}$ in THF, $0.57 \mathrm{~mL}, 2.05$ equiv) was added dropwise, and the reaction mixture was stirred at room temperature for $12 \mathrm{~h}$, at which time the rhodium chloride had been fully converted, as determined by ${ }^{31} \mathrm{P}$ NMR spectroscopy. The volatile materials were removed under reduced pressure, and the product was extracted into toluene. The solution was filtered through Celite, concentrated, and cooled at -35 ${ }^{\circ} \mathrm{C}$ to afford the crude product as a light-orange precipitate. Further purification was achieved by crystallization from toluene/pentane at $-35{ }^{\circ} \mathrm{C}$ to give $\mathbf{8}$ as light-orange crystals $(280 \mathrm{mg}, 87 \%$ yield). ${ }^{1} \mathrm{H}$ NMR (400 MHz, THF- $\left.d_{8}\right): \delta$ 0.85-0.95 (m, 18H), 1.05-1.15 (m, 9H), 1.24-1.36 (m, 12H), 1.55-1.62 (m, 6H), $2.04(\mathrm{~s}, 3 \mathrm{H}), 2.56(\mathrm{~s}, 6 \mathrm{H}), 6.36(\mathrm{~s}, 2 \mathrm{H}) .{ }^{13} \mathrm{C}$ NMR $(100.6 \mathrm{MHz}$, THF$\left.d_{8}\right): \delta 10.1,10.5,20.8(\mathrm{t}, J=10.5 \mathrm{~Hz}), 21.7(\mathrm{~d}, J=15.3 \mathrm{~Hz}), 22.4,30.3,126.7,131.8,146.0,172.4$ $\left(\mathrm{ddt}, J_{1}=77.6 \mathrm{~Hz}, J_{2}=28.3 \mathrm{~Hz}, J_{3}=17.3 \mathrm{~Hz}\right) .{ }^{31} \mathrm{P} \mathrm{NMR}\left(161.9 \mathrm{MHz}, \mathrm{C}_{6} \mathrm{D}_{6}\right): \delta 10.5\left(\mathrm{dd}, J_{\mathrm{PRh}}=155\right.$ $\left.\mathrm{Hz}, J_{\mathrm{PP}}=33 \mathrm{~Hz}\right), 14.2\left(\mathrm{dt}, J_{\mathrm{PRh}}=114 \mathrm{~Hz}, J_{\mathrm{PP}}=33 \mathrm{~Hz}\right)$. Anal. Calcd for $\mathrm{C}_{27} \mathrm{H}_{56} \mathrm{P}_{3} \mathrm{Rh}: \mathrm{C}, 56.25 ; \mathrm{H}$, 9.79. Found: C, 56.56; H, 9.59.

General Procedure for the $\beta$-Aryl Eliminations of Rh(I) Boronate Complexes 3a-d. Into a small vial was placed the rhodium boronate complex $(0.0050 \mathrm{mmol}), \mathrm{PEt}_{3}(0$ or 4.0 equiv $)$ and $1.0 \mathrm{mg}$ of 1,3,5-trimethoxybenzene as internal standard. $\mathrm{C}_{6} \mathrm{D}_{12}(0.70 \mathrm{~mL})$ was added, and the solution was stirred until it was homogeneous before being transferred to a medium-walled NMR tube equipped with a screw cap and a Teflon seal. An initial ${ }^{1} \mathrm{H}$ NMR spectrum was 
acquired. The solution was then heated in a thermostated oil bath at $50-70{ }^{\circ} \mathrm{C}$ for $20-120$ min until the starting rhodium complex was fully consumed, as determined by ${ }^{1} \mathrm{H}$ or ${ }^{31} \mathrm{P}$ NMR spectroscopy. A second ${ }^{1} \mathrm{H}$ NMR spectrum was acquired, and the yield of the rhodium aryl product $\left(\mathrm{PEt}_{3}\right)_{3} \mathrm{RhAr}(\mathbf{4 a - d})$ were calculated. Light-brown precipitates were observed when the reactions were completed, and these were presumably boroxin oligomers $[\mathrm{O}=\mathrm{B}(\mathrm{OH})]_{3}$.

$\boldsymbol{\beta}$-Aryl Elimination of $\left[\left(\mathbf{P E t}_{\mathbf{3}}\right)_{\mathbf{3}} \mathbf{R h O B}(\mathbf{O H})(\mathbf{P h})\right]$ (3a). The reaction of 3a $(2.9 \mathrm{mg}$, $0.0050 \mathrm{mmol})$ and 1,3,5-trimethoxybenzene as internal standard in $\mathrm{C}_{6} \mathrm{D}_{12}(0.7 \mathrm{~mL})$ at $50{ }^{\circ} \mathrm{C}$ for $0.5 \mathrm{~h}$ gave $88 \%$ yield of $\left(\mathrm{PEt}_{3}\right)_{3} \mathrm{Rh}(\mathrm{Ph})(\mathbf{4 a})$ as determined by ${ }^{1} \mathrm{H}$ NMR spectroscopy. The same reaction conducted with 4.0 equiv of added $\mathrm{PEt}_{3}$ at $70{ }^{\circ} \mathrm{C}$ for $1.5 \mathrm{~h}$ formed $78 \%$ of $\mathbf{4 a}$ with a slower reaction rate (half-life $\sim 900 \mathrm{~s}$ ).

$\beta$-Aryl Elimination of $\left[\left(\mathbf{P E t}_{\mathbf{3}}\right)_{3} \mathbf{R h O B}(\mathbf{O H})(p\right.$-tolyl $\left.)\right](3 \mathrm{~b})$. The reaction of $\mathbf{3 b}(3.0 \mathrm{mg}$, $0.0050 \mathrm{mmol})$ and 1,3,5-trimethoxybenzene as internal standard in $\mathrm{C}_{6} \mathrm{D}_{12}(0.7 \mathrm{~mL})$ at $50{ }^{\circ} \mathrm{C}$ for $0.5 \mathrm{~h}$ gave $80 \%$ yield of $\left(\mathrm{PEt}_{3}\right)_{3} \mathrm{Rh}(p$-tol $)(\mathbf{4 b})$ as determined by ${ }^{1} \mathrm{H}$ NMR spectroscopy. The same reaction conducted with 4.0 equiv of added $\mathrm{PEt}_{3}$ at $70{ }^{\circ} \mathrm{C}$ for $2 \mathrm{~h}$ formed $84 \%$ of $\mathbf{4 b}$ with a slower reaction rate (half-life $\sim 1400 \mathrm{~s}$ ).

$\beta$-Aryl Elimination of $\left[\left(\mathbf{P E t}_{3}\right)_{3} \mathbf{R h O B}(\mathbf{O H})(p\right.$-anisyl) $]$ (3c). The reaction of $3 \mathbf{c}(3.0 \mathrm{mg}$, $0.0050 \mathrm{mmol})$ and 1,3,5-trimethoxybenzene as internal standard in $\mathrm{C}_{6} \mathrm{D}_{12}(0.7 \mathrm{~mL})$ at $50{ }^{\circ} \mathrm{C}$ for $0.5 \mathrm{~h}$ gave $79 \%$ yield of $\left(\mathrm{PEt}_{3}\right)_{3} \mathrm{Rh}\left(p\right.$-anisyl) (4c) as determined by ${ }^{1} \mathrm{H}$ NMR spectroscopy. The same reaction conducted with 4.0 equiv of added $\mathrm{PEt}_{3}$ at $70{ }^{\circ} \mathrm{C}$ for $2 \mathrm{~h}$ formed $74 \%$ of $4 \mathrm{c}$ with a slower reaction rate (half-life $\sim 1400 \mathrm{~s}$ ).

$\beta$-Aryl Elimination of $\left[\left(\mathbf{P E t}_{3}\right)_{3} \mathbf{R h O B}(\mathbf{O H})\left(4-\mathrm{CF}_{3} \mathbf{C}_{6} \mathbf{H}_{4}\right)\right]$ (3d). The reaction of $\mathbf{3 d}(3.2$ $\mathrm{mg}, 0.0050 \mathrm{mmol})$ and 1,3,5-trimethoxybenzene as internal standard in $\mathrm{C}_{6} \mathrm{D}_{12}(0.7 \mathrm{~mL})$ at $50{ }^{\circ} \mathrm{C}$ for 20 min gave $82 \%$ yield of $\left(\mathrm{PEt}_{3}\right)_{3} \mathrm{Rh}\left(p-\mathrm{CF}_{3} \mathrm{C}_{6} \mathrm{H}_{6}\right)$ (4d) as determined by ${ }^{1} \mathrm{H} \mathrm{NMR}$ 
spectroscopy. The same reaction conducted with 4.0 equiv of added $\mathrm{PEt}_{3}$ at $70{ }^{\circ} \mathrm{C}$ for $1 \mathrm{~h}$ formed $82 \%$ of $\mathbf{4 d}$ with a slower reaction rate (half-life $\sim 500 \mathrm{~s}$ ).

$\beta$-Aryl Eliminations of in situ Generated $\left[\left(\mathrm{PEt}_{3}\right)_{3} \operatorname{RhOB}(\mathrm{OH})(o\right.$-anisyl)] (3e). Into a small vial was placed $1.0 \mathrm{mg}$ of 1,3,5-trimethoxybenzene (internal standard), $\mathrm{C}_{6} \mathrm{D}_{12}(0.50 \mathrm{~mL})$ and $o$-anisylboronic acid $(\mathbf{2 e}, 1.3 \mathrm{mg}, 0.010 \mathrm{mmol})$. The mixture was stirred at room temperature until it was homogeneous before being transferred to an NMR tube equipped with a screw cap and a Teflon seal. An initial ${ }^{1} \mathrm{H}$ NMR spectrum was acquired. $\left(\mathrm{PEt}_{3}\right)_{2} \mathrm{RhN}\left(\mathrm{SiMe}_{3}\right)_{2}(5.0 \mathrm{mg}, 1.0$ equiv) and $\mathrm{PEt}_{3}\left(5.9 \mathrm{mg}, 5.0\right.$ equiv) were quickly added as a $\mathrm{C}_{6} \mathrm{D}_{12}$ solution $(0.20 \mathrm{~mL})$ by syringe, and the mixture was briefly shaken (in less than $30 \mathrm{sec}$ ) to allow good mixing and quantitative generation of the rhodium boronate $3 \mathbf{e}$. The solution was then heated in a thermostated oil bath at $70{ }^{\circ} \mathrm{C}$ for $5 \mathrm{~min}$ and the starting rhodium complex was fully consumed, as determined by ${ }^{1} \mathrm{H}$ or

${ }^{31} \mathrm{P}$ NMR spectroscopy. A second ${ }^{1} \mathrm{H}$ NMR spectrum was acquired, and the yields of the $\beta$-aryl elimination products $\left(\mathrm{PEt}_{3}\right)_{3} \mathrm{Rh}(o$-anisyl) $(\mathbf{4 e})$ was calculated to be $>95 \%$.

$\beta$-Aryl Elimination of $\left[\left(\mathbf{P E t}_{3}\right)_{3} \mathbf{R h O B}(2 \text {-mesityl })_{2}\right]$ (7). Into a small vial was placed 7 (3.6 mg, $0.0050 \mathrm{mmol}$ ) and $1.0 \mathrm{mg}$ of 1,3,5-trimethoxybenzene as internal standard. $\mathrm{C}_{6} \mathrm{D}_{12}(0.70$ mL) was added, and the solution was stirred until it was homogeneous before being transferred to a medium-walled NMR tube equipped with a screw cap and a Teflon seal. An initial ${ }^{1} \mathrm{H}$ NMR spectrum was acquired. The solution was then heated in a thermostated oil bath at $80{ }^{\circ} \mathrm{C}$ for $4 \mathrm{~h}$ until the starting rhodium complex was fully consumed, as determined by ${ }^{1} \mathrm{H}$ or ${ }^{31} \mathrm{P}$ NMR spectroscopy. A second ${ }^{1} \mathrm{H}$ NMR spectrum was acquired, and the yield of the $\beta$-aryl elimination products $\left(\mathrm{PEt}_{3}\right)_{3} \mathrm{Rh}(2$-mesityl) $(\mathbf{8})$ and trimesitylboroxin $(\mathbf{9})$ were calculated to be $87 \%$ and $91 \%$ respectively. When the same reaction was carried out with 2.0 equiv of added $\mathrm{PEt}_{3}$ at $80{ }^{\circ} \mathrm{C}$ for 
$12 \mathrm{~h}$, much lower yields of $\mathbf{8}(<35 \%)$ and $\mathbf{9}(<51 \%)$ were obtained, and the reaction was slower (half-life $>2 h$ ).

Preparation of $\left\{\left[\left(\mathbf{P E t}_{3}\right)_{2} \mathbf{R h}(\mu-\mathbf{O H})\right]_{2}\right\}$ (10). Into a $20 \mathrm{~mL}$ scintillation vial equipped with a magnetic stir bar was placed $\left\{[(\mathrm{COD}) \mathrm{Rh}(\mu-\mathrm{OH})]_{2}\right\}(230 \mathrm{mg}, 0.51 \mathrm{mmol})$ and THF (5 $\mathrm{mL})$. The mixture was stirred at room temperature for $5 \mathrm{~min}$ before $\mathrm{PEt}_{3}(250 \mathrm{mg}, 2.11 \mathrm{mmol})$ was added. The solution was stirred at room temperature for another $2 \mathrm{~h}$ until full conversion was achieved, as determined by ${ }^{31} \mathrm{P}$ NMR spectroscopy. The volatile materials were evaporated under reduced pressure, affording the crude product as an orange precipitate. Further purification was achieved by crystallization from tetramethylsilane at $-35{ }^{\circ} \mathrm{C}$ to give orange crystals of $\mathbf{1 0}$ (239 mg, 66\% yield). ${ }^{1} \mathrm{H}$ NMR (400 MHz, $\left.\mathrm{C}_{6} \mathrm{D}_{6}\right): \delta-1.98$ (s, 2H, OH signals), 1.15-1.28 (m, 36H, $\mathrm{CH}_{3}$ signals for $\mathrm{PEt}_{3}$ ligands), 1.36-1.47 (m, $24 \mathrm{H}, \mathrm{CH}_{2}$ signals for $\mathrm{PEt}_{3}$ ligands). ${ }^{13} \mathrm{C} \mathrm{NMR}$ $\left(125.8 \mathrm{MHz}, \mathrm{C}_{6} \mathrm{D}_{6}\right): \delta 8.73,18.23(\mathrm{t}, J=12.0 \mathrm{~Hz}) .{ }^{31} \mathrm{P}$ NMR $\left(161.9 \mathrm{MHz}, \mathrm{C}_{6} \mathrm{D}_{6}\right): \delta 43.0(\mathrm{~d}, J=184$ Hz). Anal. Calcd for $\mathrm{C}_{24} \mathrm{H}_{62} \mathrm{O}_{2} \mathrm{P}_{4} \mathrm{Rh}_{2}$ : C, 40.46; H, 8.77. Found: C, 40.34; H, 8.90.

\section{Reaction of $\left\{\left[\left(\mathrm{PEt}_{3}\right)_{2} \mathrm{Rh}(\mu-\mathrm{OH})\right]_{2}\right\}$ (10) with $\mathrm{PhB}(\mathrm{OH})_{2}(2 \mathrm{a})$ in the Presence of Added}

PEt $_{3}$. Into a small vial was placed 10 (3.6 mg, $\left.0.0050 \mathrm{mmol}\right), \mathrm{PEt}_{3}(1.3 \mathrm{mg}, 2.2$ equiv) and 1.0 $\mathrm{mg}$ of 1,3,5-trimethoxybenzene as internal standard. $\mathrm{C}_{6} \mathrm{D}_{6}(0.50 \mathrm{~mL})$ was added, and the solution was stirred until it was homogeneous before being transferred to a medium-walled NMR tube equipped with a screw cap and a Teflon seal. An initial ${ }^{1} \mathrm{H}$ NMR spectrum was acquired. Compound 2a (1.2 mg, 2.0 equiv) was then added by syringe as a $\mathrm{C}_{6} \mathrm{D}_{6}$ solution $(0.30 \mathrm{~mL})$, and the resulting mixture was left at room temperature for $2 \mathrm{~h}$ until $\mathbf{1 0}$ was fully consumed, as determined by ${ }^{1} \mathrm{H}$ or ${ }^{31} \mathrm{P}$ NMR spectroscopy. A second ${ }^{1} \mathrm{H}$ NMR spectrum was acquired, and the yield of the boronate complex $\left[\left(\mathrm{PEt}_{3}\right)_{3} \mathrm{RhOB}(\mathrm{OH})(\mathrm{Ph})\right]$ (3a) was calculated to be $72 \%$. 


\section{Reaction of $\left\{\left[\left(\mathrm{PEt}_{3}\right)_{2} \mathrm{Rh}(\mu-\mathrm{OH})\right]_{2}\right\}(10)$ with $(\mathrm{Mes})_{2} \mathrm{~B}(\mathrm{OH})$ (5) in the Presence of}

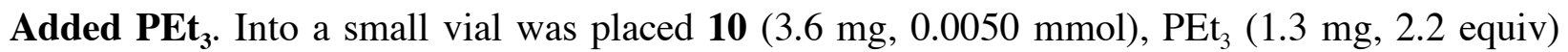
and $1.0 \mathrm{mg}$ of 1,3,5-trimethoxybenzene as internal standard $\mathrm{C}_{6} \mathrm{D}_{6}(0.50 \mathrm{~mL})$ was added, and the solution was stirred until it was homogeneous before being transferred to a medium-walled NMR tube equipped with a screw cap and a Teflon seal. An initial ${ }^{1} \mathrm{H}$ NMR spectrum was acquired. Compound 5 (2.7 mg, 2.0 equiv) was then added by syringe as a $\mathrm{C}_{6} \mathrm{D}_{6}$ solution $(0.30 \mathrm{~mL})$, and the resulting mixture was left at room temperature for $2 \mathrm{~h}$ until $\mathbf{1 0}$ was fully consumed, as determined by ${ }^{1} \mathrm{H}$ or ${ }^{31} \mathrm{P}$ NMR spectroscopy. A second ${ }^{1} \mathrm{H}$ NMR spectrum was acquired, and the yield of the formed borinate complex $\left[\left(\mathrm{PEt}_{3}\right)_{3} \mathrm{RhOB}(\mathrm{Mes})_{2}\right](7)$ was calculated to be $77 \%$.

Reaction of $\left\{\left(\mathrm{PEt}_{3}\right)_{2} \mathrm{Rh}\left[\mathrm{OC}(\mathrm{Ph})=\mathrm{CH}_{2}\right]\right\}(11)$ with $\mathrm{PhB}(\mathrm{OH})_{2}(2 \mathrm{a})$ in the Presence of

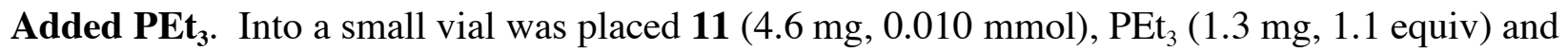
$1.0 \mathrm{mg}$ of 1,3,5-trimethoxybenzene as internal standard. $\mathrm{C}_{6} \mathrm{D}_{6}(0.50 \mathrm{~mL})$ was added, and the solution was stirred until it was homogeneous before being transferred to a medium-walled NMR tube equipped with a screw cap and a Teflon seal. An initial ${ }^{1} \mathrm{H}$ NMR spectrum was acquired. Compound 2a (1.2 mg, 1.0 equiv) was then added by syringe as a $\mathrm{C}_{6} \mathrm{D}_{6}$ solution $(0.30 \mathrm{~mL})$, and the resulting mixture was left at room temperature for $2 \mathrm{~h}$ until $\mathbf{1 1}$ was fully consumed, as determined by ${ }^{1} \mathrm{H}$ or ${ }^{31} \mathrm{P}$ NMR spectroscopy. A second ${ }^{1} \mathrm{H}$ NMR spectrum was acquired, and the yield of the formed boronate complex $\left[\left(\mathrm{PEt}_{3}\right)_{3} \mathrm{RhOB}(\mathrm{OH})(\mathrm{Ph})\right]$ (3a) and acetophenone was calculated to be $73 \%$ and $96 \%$ respectively.

\section{Representative Procedure for the Kinetic Experiments Conducted on $\beta$-Aryl}

Eliminations of $\left[\left(\mathrm{PEt}_{3}\right)_{3} \mathbf{R h O B}(\mathrm{OH})(p\right.$-tolyl $\left.)\right](3 \mathrm{~b})$ in the Presence of Added $\mathrm{PEt}_{3}$. Into a small vial was placed complex $\mathbf{3 b}(5.9 \mathrm{mg}, 0.010 \mathrm{mmol})$ and $1.0 \mathrm{mg}$ of 1,3,5-trimethoxybenzene (internal standard). $\mathrm{C}_{6} \mathrm{D}_{12}(0.70 \mathrm{~mL})$ and $\mathrm{PEt}_{3}(7.1 \mathrm{mg}, 0.060 \mathrm{mmol}, 6.0$ equiv) were added by 
syringe. The mixture was stirred at room temperature until it was homogeneous. The solution was transferred to an NMR tube equipped with a screw cap and a Teflon seal. The sample was then placed into the heated NMR probe $\left(70{ }^{\circ} \mathrm{C}\right)$, and a ${ }^{1} \mathrm{H}$ NMR spectrum was obtained at fixed intervals. This procedure was repeated using different initial concentrations of $\mathrm{PEt}_{3}$ as indicated in Figures S1-S2. 


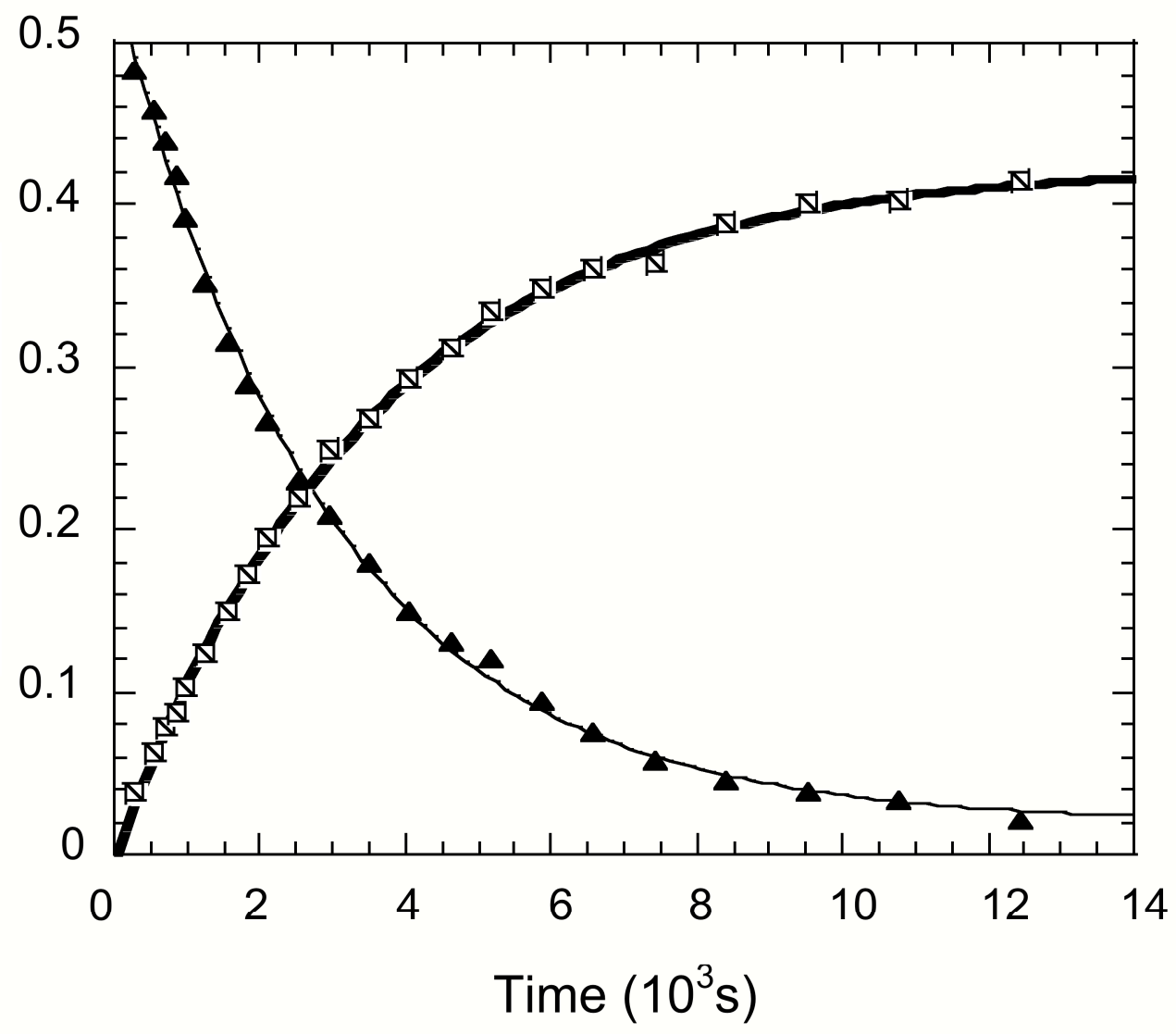

Figure S1. Representative kinetic plot for the $\beta$-aryl elimination of rhodium boronate complex $3 \mathbf{b}(0.014 \mathrm{M})$ in the presence of $\mathrm{PEt}_{3}\left(0.084 \mathrm{M}, 6.0\right.$ equiv) in $\mathrm{C}_{6} \mathrm{D}_{12}$ at $70{ }^{\circ} \mathrm{C}$. The curve for the consumption of $\mathbf{3 b}$ depicts the results of an unweighted least-square fit to $\mathrm{y}=\mathrm{a}^{*} \exp \left(-\mathrm{b}^{*} \mathrm{x}\right)+\mathrm{c}(\mathrm{a}$ $=0.520 \pm 0.005, \mathrm{~b}=0.00034 \pm 0.00001, \mathrm{c}=0.020 \pm 0.004)$. The curve for the accumulation of $\left(\mathrm{PEt}_{3}\right)_{3} \mathrm{Rh}\left(p\right.$-tolyl) (4b) depicts the results of an unweighted least-square fit to $\mathrm{y}=-\mathrm{a}^{*} \exp \left(-\mathrm{b}^{*} \mathrm{x}\right)+$ $\mathrm{c}(\mathrm{a}=0.424 \pm 0.003, \mathrm{~b}=0.00029 \pm 0.00001, \mathrm{c}=0.425 \pm 0.003)$. 


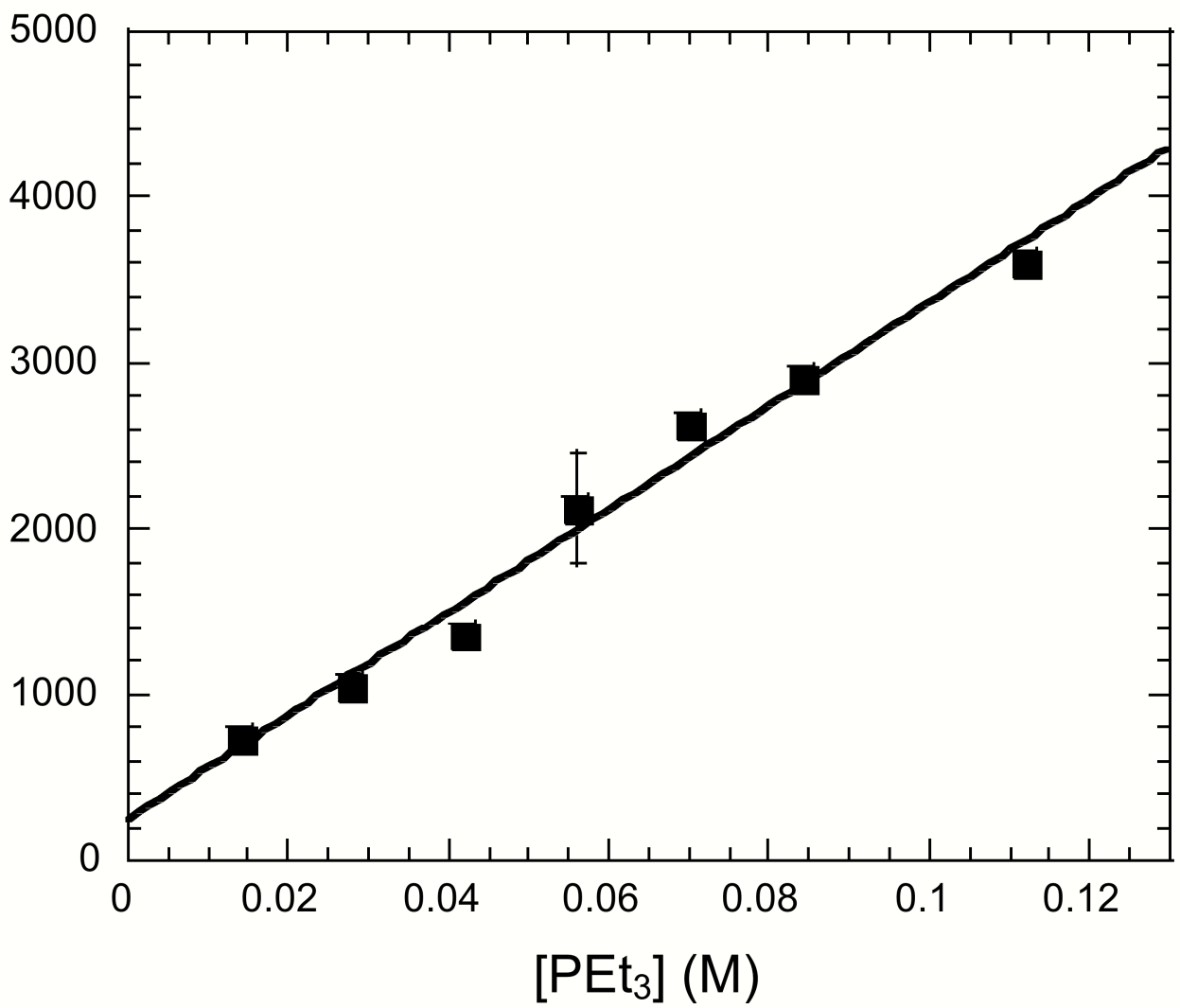

Figure S2. Plot of $1 / k_{\text {obsd }}$ vs [ $\left.\mathrm{PEt}_{3}\right]$ for the $\beta$-aryl elimination of rhodium complex $\mathbf{3 b}(0.014 \mathrm{M})$ in the presence of added $\mathrm{PEt}_{3}$ in $\mathrm{C}_{6} \mathrm{D}_{12}$ at $70{ }^{\circ} \mathrm{C}$. The curve depicts the results of an unweighted least-square fit to $\mathrm{y}=\mathrm{a}^{*} \mathrm{x}+\mathrm{b}\left(\mathrm{a}=3.1 \pm 0.2 \times 10^{4}, \mathrm{~b}=2 \pm 1 \times 10^{2}\right)$.

Table S1. Table of data for Figure S2.

\begin{tabular}{ccccc}
\hline$\left[\mathrm{PEt}_{3}\right](\mathrm{M})$ & $k_{\text {obsd1 }}\left(\mathrm{s}^{-1}\right)$ & $k_{\text {obsd } 2}\left(\mathrm{~s}^{-1}\right)$ & Average $k_{\text {obsd }}\left(\mathrm{s}^{-1}\right)$ & $1 / k_{\text {obsd }}(\mathrm{s})$ \\
\hline 0.014 & 0.00138 & & 0.00138 & 724 \\
0.028 & 0.00095 & & 0.00095 & 1050 \\
0.042 & 0.00074 & & 0.00074 & 1350 \\
0.056 & 0.00041 & 0.00053 & $0.00047 \pm 0.00006$ & $2100 \pm 300$ \\
0.070 & 0.00038 & & 0.00038 & 2630 \\
0.084 & 0.00034 & & 0.00034 & 2920 \\
0.110 & 0.00028 & & 0.00028 & 3610 \\
\hline
\end{tabular}




\section{References}

1) Van der Ent, A.; Onderdelinden, A. L. Inorg. Syn. 1973, 14, 92.

2) Zhao, P.; Krug, C.; Hartwig, J. F. J. Am. Chem. Soc. 2005, 127, 12066.

3) Zhao, P.; Hartwig, J. F. J. Am. Chem. Soc. 2005, 127, 11618.

4) Anulewicz-Ostrowska, R; Lulinski, S; Serwatowski, J; Suwinska, K. Inorg. Chem. 2000, 39, 5763.

5) Uson, R.; Oro, L. A.; Cabeza, J. A. Inorganic Syntheses 1985, 23, 1260.

6) Slough, G. A.; Hayashi, R.; Ashbaugh, J. R.; Shamblin, S. L.; Aukamp, A. M. Organometallics 1994, 13, 890 . 


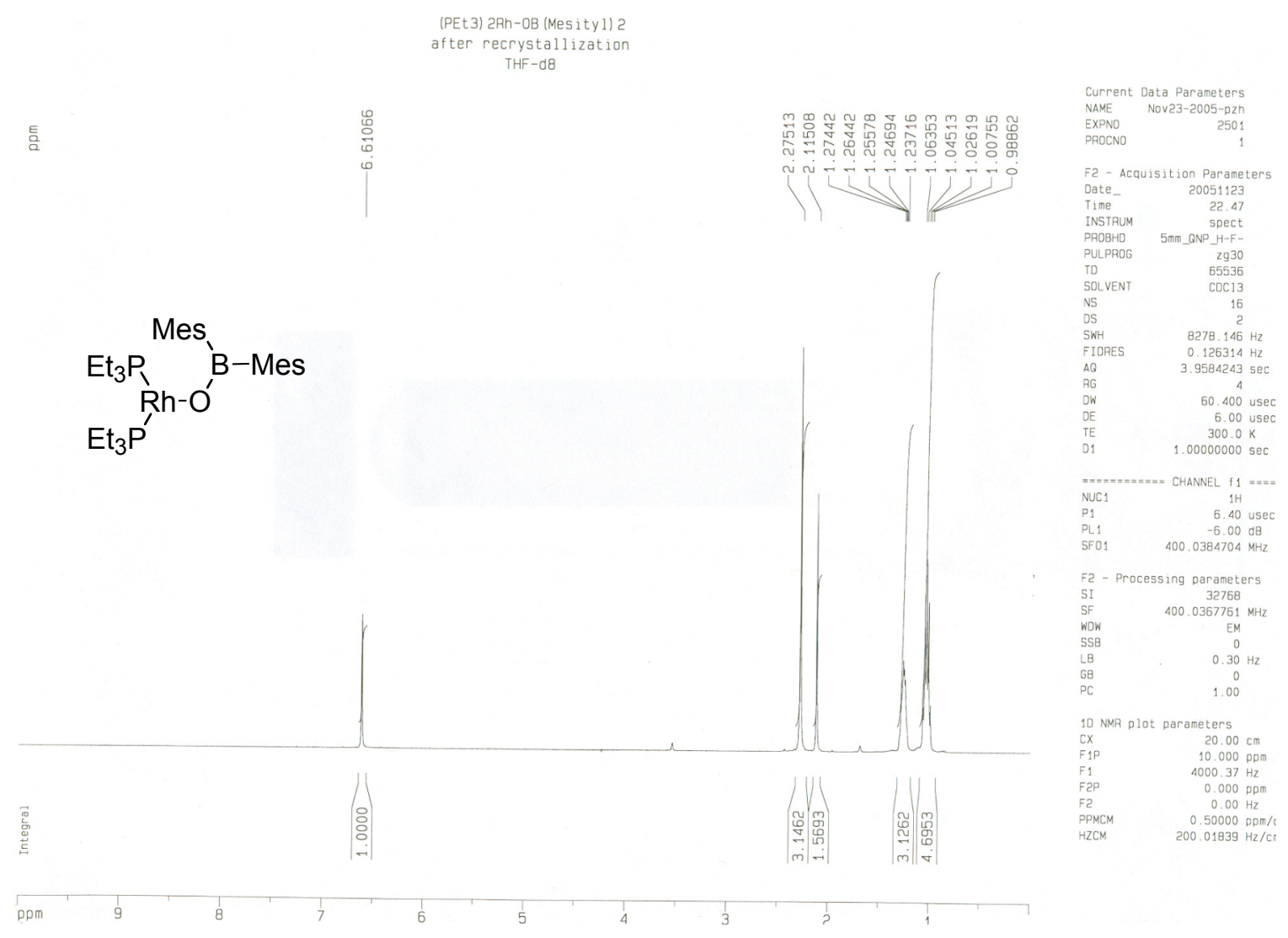

Figure S3. ${ }^{1} \mathrm{H}$ NMR spectrum (THF- $\left.d_{8}, 400 \mathrm{MHz}\right)$ of $\left[\left(\mathrm{PEt}_{3}\right)_{2} \mathrm{RhOB}(2 \text {-mesityl })_{2}\right](\mathbf{6})$. 


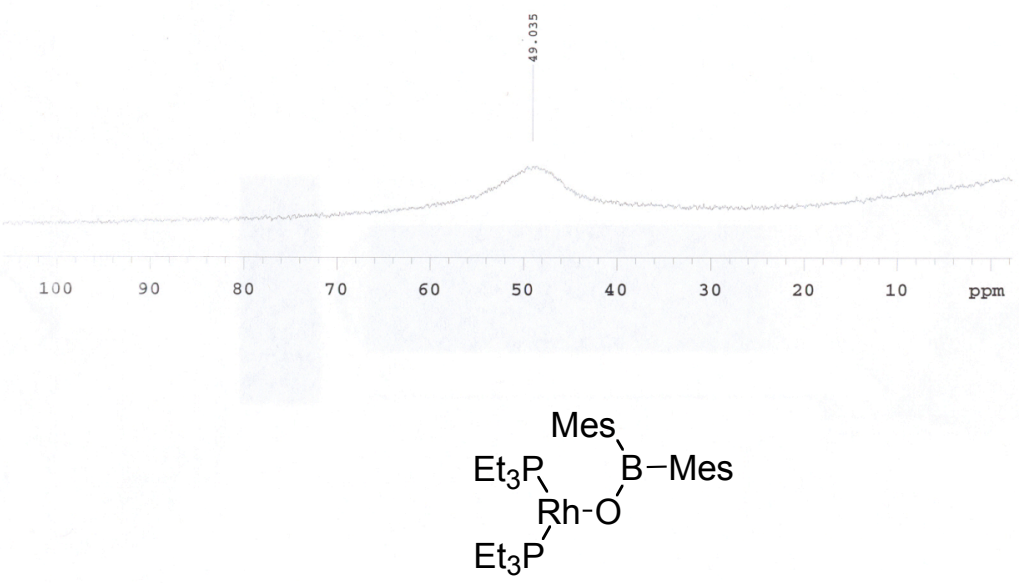

Figure S4. ${ }^{11} \mathrm{~B}$ NMR spectrum (THF, $\left.96.3 \mathrm{MHz}\right)$ of $\left[\left(\mathrm{PEt}_{3}\right)_{2} \mathrm{RhOB}(2-\text { mesityl })_{2}\right](6)$. 


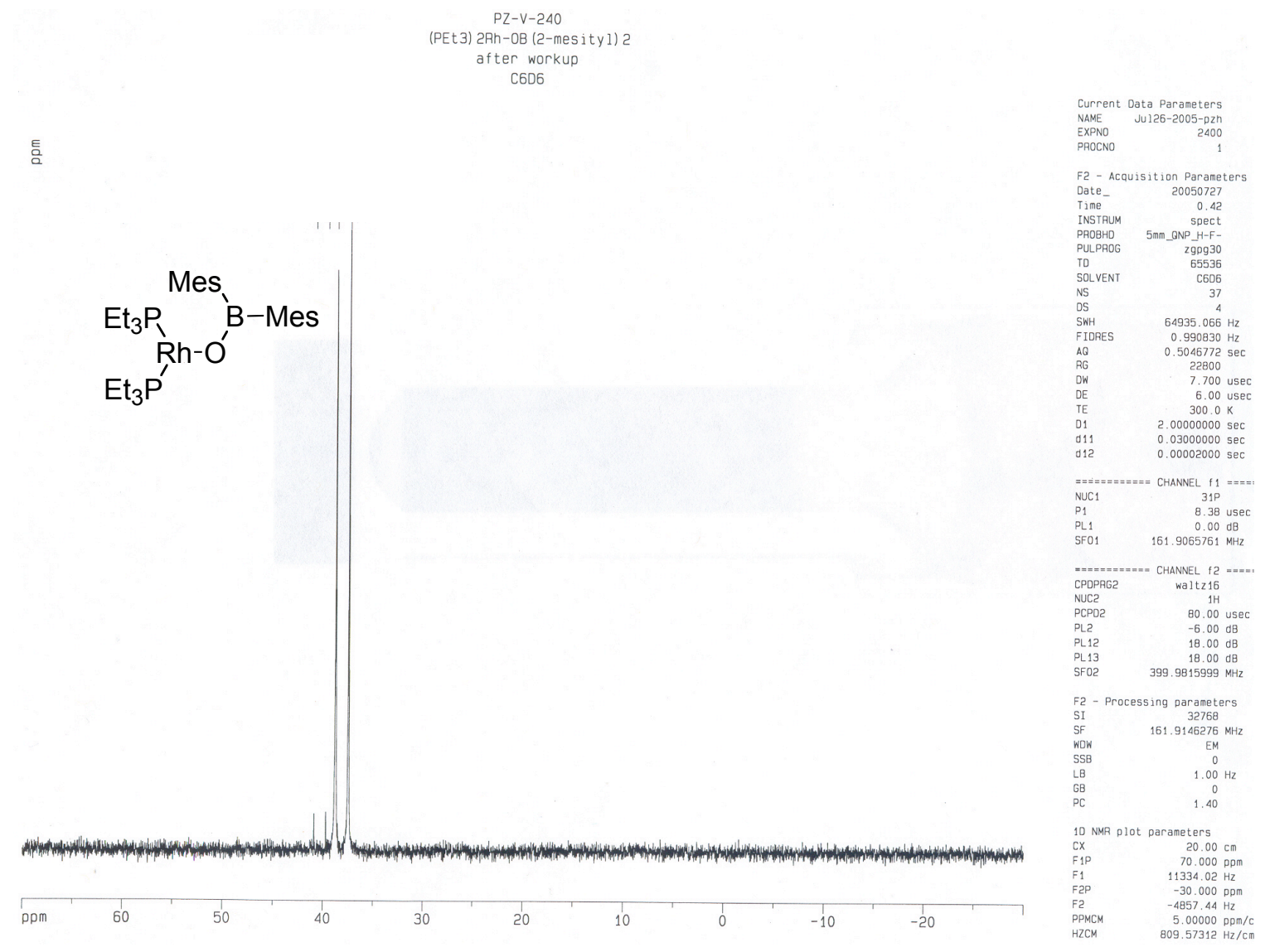

Figure S5. ${ }^{31} \mathrm{P}$ NMR spectrum $\left(\mathrm{C}_{6} \mathrm{D}_{6}, 161.9 \mathrm{MHz}\right)$ of $\left[\left(\mathrm{PEt}_{3}\right)_{2} \mathrm{RhOB}(2 \text {-mesityl })_{2}\right](6)$. 


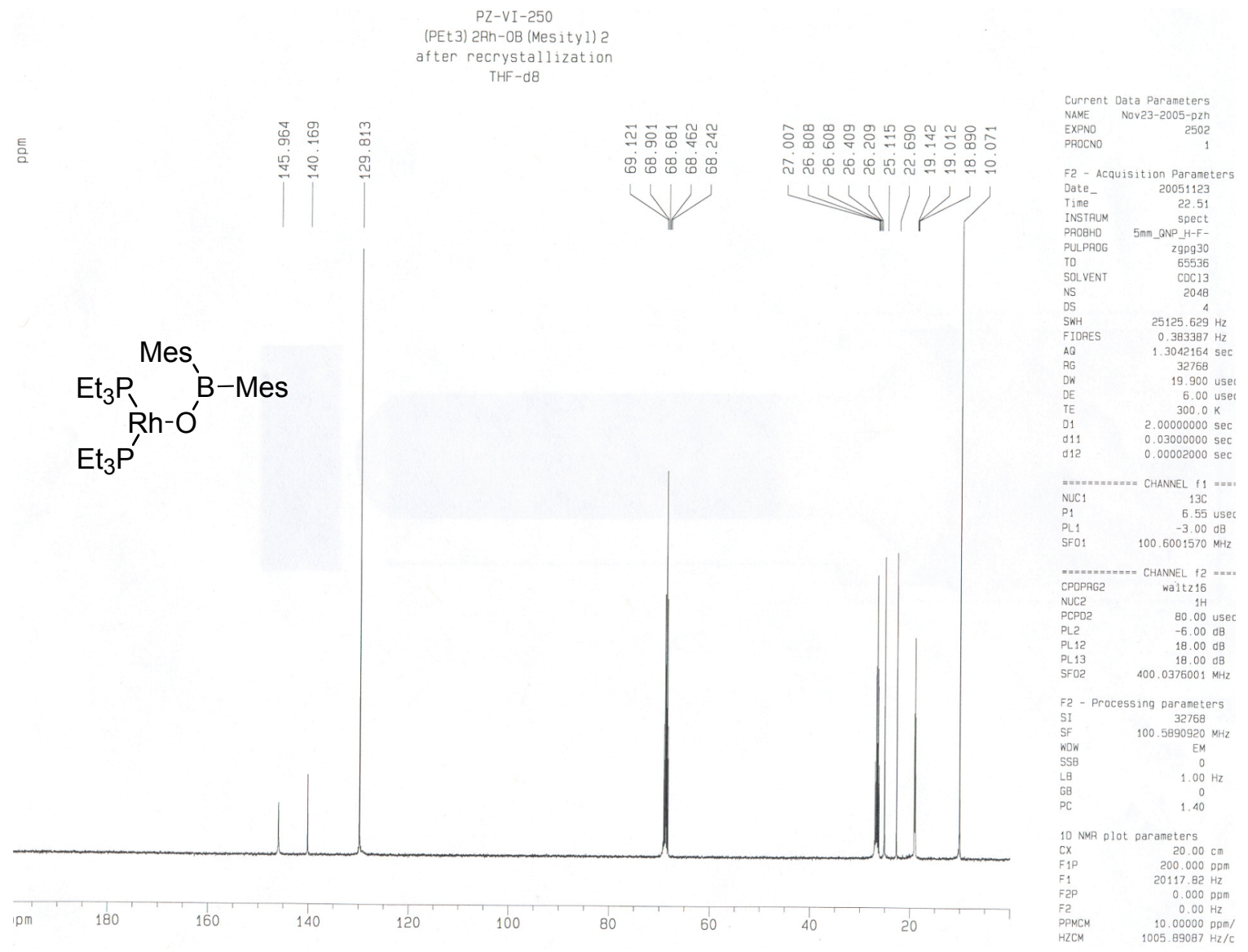

Figure S6. ${ }^{13} \mathrm{C}$ NMR spectrum $\left(\mathrm{THF}-d_{8}, 100.6 \mathrm{MHz}\right)$ of $\left[\left(\mathrm{PEt}_{3}\right)_{2} \mathrm{RhOB}(2 \text {-mesityl })_{2}\right](6)$. 
Experimental Procedure for the X-ray Diffraction of $\left[\left(\mathrm{PEt}_{3}\right)_{2} \mathrm{RhOB}(\mathrm{OH})(p\right.$-tolyl $\left.)\right](\mathbf{3 b})$

\section{Data Collection}

A yellow block crystal of $\mathrm{C}_{25} \mathrm{H}_{53} \mathrm{O}_{2} \mathrm{P}_{3} \mathrm{Rh} \cdot 0.5 \mathrm{C}_{5} \mathrm{H}_{12}, \mathrm{C}_{27.5} \mathrm{H}_{59} \mathrm{BO}_{2} \mathrm{P}_{3} \mathrm{Rh}$ (3b), having approximate dimensions of $0.20 \times 0.20 \times 0.15 \mathrm{~mm}^{3}$ was mounted with epoxy cement on the tip of a fine glass fiber. All measurements were made on a Nonius KappaCCD diffractometer with graphite monochromated Mo-K $\alpha$ radiation.

Cell constants and an orientation matrix for data collection corresponded to a primitive monoclinic cell with dimensions:

$$
\begin{array}{ll}
\mathrm{a}=10.693(2) \AA & \alpha=90^{\circ} \\
\mathrm{b}=17.341(4) \AA & \beta=106.35(3) \mathrm{O} \\
\mathrm{c}=18.915(4) \AA & \gamma=90^{\circ} \\
\mathrm{V}=3365.6(12) \AA^{3} &
\end{array}
$$

For $\mathrm{Z}=4$ and F.W. $=628.38$, the calculated density is $1.240 \mathrm{~g} / \mathrm{cm}^{3}$. Based on a statistical analysis of intensity distribution, and the successful solution and refinement of the structure, the space group was determined to be $P 2_{1} / n$ (\#14).

The data were collected at a temperature of $173(2) \mathrm{K}$ to a maximum $2 \theta$ value of $56.58^{\circ}$. Four omega scans consisting of $43,47,44$, and 18 data frames, respectively, were collected with a frame width of $1.6^{\circ}$ and a detector-to-crystal distance, Dx, of $35.0 \mathrm{~mm}$. Each frame was exposed twice (for the purpose of de-zingering) for a total of $48 \mathrm{~s}$. The data frames were processed and scaled using the DENZO software package. ${ }^{1}$

\section{Data Reduction}

A total of 13740 reflections were collected of which 8310 were unique and observed $\left(R_{\text {int }}\right.$ $=0.0359)$. The linear absorption coefficient, $\mu$, for Mo-K $\alpha$ radiation is $6.71 \mathrm{~cm}^{-1}$, and no absorption correction was applied. The data were corrected for Lorentz and polarization effects.

\section{$\underline{\text { Structure Solution and Refinement }}$}

The structure was solved by direct methods and expanded using Fourier techniques ${ }^{2}$. The non-hydrogen atoms were refined anisotropically and hydrogen atoms, with exceptions noted, were treated as idealized contributions. The final cycle of full-matrix least-squares refinement ${ }^{3}$ on F was based on 8310 observed reflections (I > 2.00\%(I)) and 327 variable parameters and converged with unweighted and weighted agreement factors of:

$$
\begin{gathered}
\mathrm{R}=\Sigma\|\mathrm{Fol}-|\mathrm{Fc} \| / \Sigma| \mathrm{Fo} \mid=0.0388 \\
\mathrm{R}_{\mathrm{W}}=\left\{\Sigma\left[\mathrm{w}\left(\mathrm{F}_{\mathrm{o}}^{2}-\mathrm{F}_{\mathrm{c}}^{2}\right)^{2}\right] / \Sigma\left[\mathrm{w}\left(\mathrm{F}_{\mathrm{o}}^{2}\right)^{2}\right]\right\}^{1 / 2}=0.0868
\end{gathered}
$$

The maximum and minimum peaks on the final difference Fourier map corresponded to 0.436 and $-0.574 \mathrm{e}^{-} / \AA^{3}$ respectively. 
The compound crystallized in the monoclinic space group $P 2_{1} / n$ with one molecule in the asymmetric unit and four molecules in the unit cell. H(2) was located from the residual electron difference map and freely refined with isotropic displacement parameters. No geometric restraints were applied to the $\mathrm{O}(2)-\mathrm{H}(2)$ bond, which refined to a distance of $0.97(3) \AA$. $\mathrm{H}(2)$ is hydrogen bonded to $\mathrm{O}(1)$ of an adjacent molecule. The interaction with the adjacent molecule is reciprocating and the dimeric structure forms an eight-member ring as illustrated in Figure 4. The interatomic distances wre $1.75 \AA$ for $\mathrm{H}(2) \cdots \mathrm{O}(1)$ and $2.71 \AA$ for $\mathrm{O}(2) \cdots \mathrm{O}(1)$. The $\mathrm{O}(2)$ $\mathrm{H}(2) \cdots \mathrm{O}(1)$ angle was $170.3^{\circ}$.

Pentane co-crystallized with the rhodium-complex in a ratio of 1:2. The solvent molecule resides on a crystallographic inversion center and possesses positional disorder in the crystallographically unique portion. The disorder was successfully modeled, and the components were refined anisotropically with an occupancy factor ratio of 70:30.

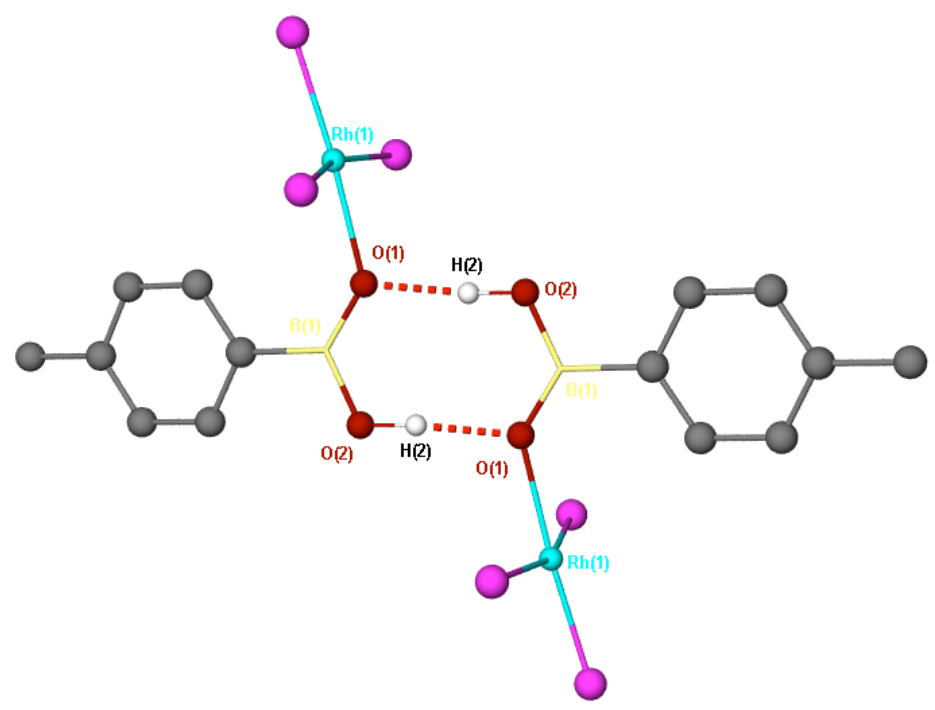

Figure S7. Intermolecular contacts in the solid-state structure of $\mathbf{3 b}$.

\section{References for the X-ray diffraction studies:}

(1) Z. Otwinowski and W. Minor, "Processing of X-Ray Diffraction Data Collected in Oscillation Mode," Methods in Enzymology, vol. 276: Macromolecular Crystallography, part A, 307-326, 1997, C.W. Carter, Jr. \& R.M. Sweet, Eds., Academic Press.

(2) Acta Cryst. A46 (1990) 467-473

(3) Least Squares function minimized:

$$
\Sigma w\left(\mathrm{~F}_{\mathrm{o}}^{2}-\mathrm{F}_{\mathrm{c}}^{2}\right)^{2}
$$


Table S2. Crystal data and structure refinement for $3 b^{\bullet} 0.5 C_{5} H_{12}$.

Empirical formula

Formula weight

Temperature

Wavelength

Crystal system

Space group

Unit cell dimensions

Volume

Z

Density (calculated)

Absorption coefficient

$\mathrm{F}(000)$

Crystal size

Theta range for data collection

Index ranges

Reflections collected

Independent reflections

Completeness to theta $=28.29^{\circ}$

Absorption correction

Max. and min. transmission

Refinement method

Data / restraints / parameters

Goodness-of-fit on $\mathrm{F}^{2}$

Final $\mathrm{R}$ indices [I $>2 \operatorname{sigma}(\mathrm{I})]$

$\mathrm{R}$ indices (all data)

Largest diff. peak and hole
$\mathrm{C}_{27.50} \mathrm{H}_{59} \mathrm{~B} \mathrm{O}_{2} \mathrm{P}_{3} \mathrm{Rh}$

628.38

173(2) K

$0.71073 \AA$

Monoclinic

$\mathrm{P} 2(1) / \mathrm{n}$

$\mathrm{a}=10.693(2) \AA \quad \alpha=90^{\circ}$.

$\mathrm{b}=17.341(4) \AA$

$\beta=106.35(3)^{\circ}$.

$\mathrm{c}=18.915(4) \AA$

$\gamma=90^{\circ}$.
4

$1.240 \mathrm{~g} / \mathrm{cm}^{3}$

$6.71 \mathrm{~cm}^{-1}$

1340

$0.20 \times 0.20 \times 0.15 \mathrm{~mm}^{3}$

3.08 to $28.29^{\circ}$.

$-14<=\mathrm{h}<=14,-23<=\mathrm{k}<=20,-25<=1<=25$

13740

$8310[\mathrm{R}(\mathrm{int})=0.0359]$

$99.3 \%$

None

0.9061 and 0.8775

Full-matrix least-squares on $\mathrm{F}^{2}$

8310 / 0 / 327

1.046

$\mathrm{R} 1=0.0388, \mathrm{wR} 2=0.0868$

$\mathrm{R} 1=0.0693, \mathrm{wR} 2=0.0960$

0.436 and -0.574 e. $\AA^{-3}$ 
Table S3. Atomic coordinates ( x 104) and equivalent isotropic displacement parameters $\left(\AA^{2} \mathrm{x}\right.$ $10^{3}$ ) for $\mathbf{3 b}$ (with 0.5 equiv of pentane contained in the crystals). $U(\mathrm{eq})$ is defined as one third of the trace of the orthogonalized $\mathrm{U}^{\mathrm{ij}}$ tensor.

\begin{tabular}{|c|c|c|c|c|}
\hline & $\mathrm{x}$ & $\mathrm{y}$ & z & $\mathrm{U}(\mathrm{eq})$ \\
\hline $\mathrm{Rh}(1)$ & $6630(1)$ & $3109(1)$ & $5641(1)$ & $27(1)$ \\
\hline $\mathrm{P}(1)$ & $7256(1)$ & $3251(1)$ & $4560(1)$ & $33(1)$ \\
\hline $\mathrm{P}(2)$ & $5468(1)$ & $3179(1)$ & $6509(1)$ & $32(1)$ \\
\hline $\mathrm{P}(3)$ & $7219(1)$ & 1891(1) & $5830(1)$ & $31(1)$ \\
\hline $\mathrm{O}(1)$ & $6203(2)$ & $4284(1)$ & $5428(1)$ & $33(1)$ \\
\hline $\mathrm{O}(2)$ & $6323(2)$ & $5644(1)$ & $5392(1)$ & $44(1)$ \\
\hline $\mathrm{B}(1)$ & $6833(3)$ & $4937(2)$ & $5666(2)$ & $34(1)$ \\
\hline $\mathrm{C}(1)$ & $5887(3)$ & $3648(2)$ & $3851(2)$ & $42(1)$ \\
\hline$C(2)$ & $4698(3)$ & $3124(2)$ & $3645(2)$ & $58(1)$ \\
\hline $\mathrm{C}(3)$ & $7724(4)$ & $2455(2)$ & $4042(2)$ & $57(1)$ \\
\hline$C(4)$ & $8018(3)$ & $2634(2)$ & $3328(2)$ & $59(1)$ \\
\hline$C(5)$ & $8507(3)$ & $3976(2)$ & $4580(2)$ & $46(1)$ \\
\hline$C(6)$ & $9886(3)$ & $3727(2)$ & $5016(2)$ & $72(1)$ \\
\hline$C(7)$ & $3984(3)$ & $2586(2)$ & $6298(2)$ & $44(1)$ \\
\hline$C(8)$ & $3023(3)$ & $2786(2)$ & $5559(2)$ & $59(1)$ \\
\hline$C(9)$ & $4817(3)$ & $4158(2)$ & $6559(2)$ & $41(1)$ \\
\hline$C(10)$ & $3904(4)$ & $4270(2)$ & $7047(2)$ & $66(1)$ \\
\hline $\mathrm{C}(11)$ & $6153(3)$ & 2954(1) & $7493(2)$ & $39(1)$ \\
\hline$C(12)$ & $7439(3)$ & $3362(2)$ & $7840(2)$ & $56(1)$ \\
\hline$C(13)$ & $6433(3)$ & $1171(2)$ & $5126(2)$ & $45(1)$ \\
\hline$C(14)$ & $4955(3)$ & $1114(2)$ & $4985(2)$ & $68(1)$ \\
\hline$C(15)$ & $7096(3)$ & $1400(1)$ & $6674(2)$ & $39(1)$ \\
\hline$C(16)$ & $7600(4)$ & $562(2)$ & $6811(2)$ & $62(1)$ \\
\hline$C(17)$ & $8951(3)$ & 1711(2) & $5907(2)$ & $42(1)$ \\
\hline$C(18)$ & $9895(3)$ & $2093(2)$ & $6571(2)$ & $57(1)$ \\
\hline C(19) & 8193(3) & 4999(1) & $6285(2)$ & $37(1)$ \\
\hline$C(20)$ & $8732(3)$ & $5712(2)$ & $6553(2)$ & $46(1)$ \\
\hline $\mathrm{C}(21)$ & $9866(3)$ & $5768(2)$ & $7126(2)$ & $51(1)$ \\
\hline$C(22)$ & $10520(3)$ & $5124(2)$ & $7462(2)$ & $53(1)$ \\
\hline$C(23)$ & $10012(3)$ & $4413(2)$ & $7198(2)$ & $57(1)$ \\
\hline
\end{tabular}




\begin{tabular}{lcclr}
$\mathrm{C}(24)$ & $8870(3)$ & $4355(2)$ & $6626(2)$ & $45(1)$ \\
$\mathrm{C}(25)$ & $11741(3)$ & $5186(2)$ & $8106(2)$ & $80(1)$ \\
$\mathrm{C}(26)$ & 0 & 0 & 5000 & $141(5)$ \\
$\mathrm{C}(27)$ & $988(10)$ & $647(5)$ & $4920(5)$ & $122(3)$ \\
$\mathrm{C}\left(27^{\prime}\right)$ & $-64(11)$ & $400(6)$ & $4439(6)$ & $34(2)$ \\
$\mathrm{C}(28)$ & $1007(5)$ & $1067(3)$ & $4402(4)$ & $125(2)$ \\
\hline
\end{tabular}


Table S4. Bond lengths $[\AA]$ and angles $\left[^{\circ}\right]$ for $\mathbf{3 b}$ (with 0.5 equiv of pentane contained in the crystals).

\begin{tabular}{|c|c|c|c|}
\hline $\mathrm{Rh}(1)-\mathrm{O}(1)$ & $2.1023(16)$ & $\mathrm{C}(26)-\mathrm{C}\left(27^{\prime}\right)$ & $1.253(9)$ \\
\hline $\mathrm{Rh}(1)-\mathrm{P}(3)$ & $2.2043(7)$ & $\mathrm{C}(26)-\mathrm{C}\left(27^{\prime}\right) \# 1$ & $1.253(9)$ \\
\hline $\mathrm{Rh}(1)-\mathrm{P}(2)$ & $2.3240(9)$ & $\mathrm{C}(26)-\mathrm{C}(27)$ & $1.577(11)$ \\
\hline $\mathrm{Rh}(1)-\mathrm{P}(1)$ & $2.3360(8)$ & $\mathrm{C}(26)-\mathrm{C}(27) \# 1$ & $1.577(11)$ \\
\hline $\mathrm{P}(1)-\mathrm{C}(1)$ & $1.820(3)$ & $\mathrm{C}(27)-\mathrm{C}(28)$ & $1.226(8)$ \\
\hline$P(1)-C(5)$ & $1.828(3)$ & $C\left(27^{\prime}\right)-C(28)$ & $1.643(12)$ \\
\hline $\mathrm{P}(1)-\mathrm{C}(3)$ & $1.843(3)$ & & \\
\hline$P(2)-C(7)$ & $1.839(3)$ & $\mathrm{O}(1)-\mathrm{Rh}(1)-\mathrm{P}(3)$ & $175.24(5)$ \\
\hline $\mathrm{P}(2)-\mathrm{C}(11)$ & $1.841(3)$ & $\mathrm{O}(1)-\mathrm{Rh}(1)-\mathrm{P}(2)$ & $87.37(5)$ \\
\hline $\mathrm{P}(2)-\mathrm{C}(9)$ & $1.846(2)$ & $\mathrm{P}(3)-\mathrm{Rh}(1)-\mathrm{P}(2)$ & $96.97(2)$ \\
\hline $\mathrm{P}(3)-\mathrm{C}(17)$ & $1.843(3)$ & $\mathrm{O}(1)-\mathrm{Rh}(1)-\mathrm{P}(1)$ & $80.21(5)$ \\
\hline$P(3)-C(13)$ & $1.846(3)$ & $\mathrm{P}(3)-\mathrm{Rh}(1)-\mathrm{P}(1)$ & $95.96(2)$ \\
\hline $\mathrm{P}(3)-\mathrm{C}(15)$ & $1.847(3)$ & $\mathrm{P}(2)-\mathrm{Rh}(1)-\mathrm{P}(1)$ & $162.60(3)$ \\
\hline $\mathrm{O}(1)-\mathrm{B}(1)$ & $1.330(3)$ & $\mathrm{C}(1)-\mathrm{P}(1)-\mathrm{C}(5)$ & $100.79(13)$ \\
\hline $\mathrm{O}(2)-\mathrm{H}(2)$ & $0.97(3)$ & $\mathrm{C}(1)-\mathrm{P}(1)-\mathrm{C}(3)$ & 99.99(15) \\
\hline $\mathrm{O}(2)-\mathrm{B}(1)$ & $1.382(3)$ & $\mathrm{C}(5)-\mathrm{P}(1)-\mathrm{C}(3)$ & $102.67(15)$ \\
\hline $\mathrm{B}(1)-\mathrm{C}(19)$ & $1.593(4)$ & $\mathrm{C}(1)-\mathrm{P}(1)-\mathrm{Rh}(1)$ & $108.42(9)$ \\
\hline$C(1)-C(2)$ & $1.522(4)$ & $\mathrm{C}(5)-\mathrm{P}(1)-\mathrm{Rh}(1)$ & $116.30(10)$ \\
\hline$C(3)-C(4)$ & $1.503(4)$ & $\mathrm{C}(3)-\mathrm{P}(1)-\mathrm{Rh}(1)$ & $125.03(10)$ \\
\hline$C(5)-C(6)$ & $1.535(4)$ & $C(7)-P(2)-C(11)$ & $100.01(13)$ \\
\hline$C(7)-C(8)$ & $1.524(4)$ & $C(7)-P(2)-C(9)$ & $102.15(13)$ \\
\hline$C(9)-C(10)$ & $1.534(4)$ & $\mathrm{C}(11)-\mathrm{P}(2)-\mathrm{C}(9)$ & $101.04(13)$ \\
\hline$C(11)-C(12)$ & $1.521(4)$ & $\mathrm{C}(7)-\mathrm{P}(2)-\mathrm{Rh}(1)$ & $114.73(10)$ \\
\hline$C(13)-C(14)$ & $1.530(4)$ & $\mathrm{C}(11)-\mathrm{P}(2)-\mathrm{Rh}(1)$ & $124.30(9)$ \\
\hline$C(15)-C(16)$ & $1.546(4)$ & $\mathrm{C}(9)-\mathrm{P}(2)-\mathrm{Rh}(1)$ & $111.64(9)$ \\
\hline$C(17)-C(18)$ & $1.524(4)$ & $C(17)-P(3)-C(13)$ & $100.74(13)$ \\
\hline$C(19)-C(24)$ & $1.388(4)$ & $\mathrm{C}(17)-\mathrm{P}(3)-\mathrm{C}(15)$ & $99.67(13)$ \\
\hline$C(19)-C(20)$ & $1.397(4)$ & $C(13)-P(3)-C(15)$ & $100.53(13)$ \\
\hline$C(20)-C(21)$ & $1.384(4)$ & $\mathrm{C}(17)-\mathrm{P}(3)-\mathrm{Rh}(1)$ & $114.21(9)$ \\
\hline $\mathrm{C}(21)-\mathrm{C}(22)$ & $1.374(4)$ & $\mathrm{C}(13)-\mathrm{P}(3)-\mathrm{Rh}(1)$ & 118.69(10) \\
\hline$C(22)-C(23)$ & $1.383(4)$ & $\mathrm{C}(15)-\mathrm{P}(3)-\mathrm{Rh}(1)$ & $119.66(8)$ \\
\hline$C(22)-C(25)$ & $1.518(5)$ & $\mathrm{B}(1)-\mathrm{O}(1)-\mathrm{Rh}(1)$ & $134.30(17)$ \\
\hline $\mathrm{C}(23)-\mathrm{C}(24)$ & $1.388(4)$ & $\mathrm{H}(2)-\mathrm{O}(2)-\mathrm{B}(1)$ & $115.0(17)$ \\
\hline
\end{tabular}




$\begin{array}{lllr}\mathrm{O}(1)-\mathrm{B}(1)-\mathrm{O}(2) & 121.3(3) & \mathrm{C}(22)-\mathrm{C}(21)-\mathrm{C}(20) & 121.7(3) \\ \mathrm{O}(1)-\mathrm{B}(1)-\mathrm{C}(19) & 125.3(2) & \mathrm{C}(21)-\mathrm{C}(22)-\mathrm{C}(23) & 117.4(3) \\ \mathrm{O}(2)-\mathrm{B}(1)-\mathrm{C}(19) & 113.4(2) & \mathrm{C}(21)-\mathrm{C}(22)-\mathrm{C}(25) & 121.6(3) \\ \mathrm{C}(2)-\mathrm{C}(1)-\mathrm{P}(1) & 113.8(2) & \mathrm{C}(23)-\mathrm{C}(22)-\mathrm{C}(25) & 121.0(3) \\ \mathrm{C}(4)-\mathrm{C}(3)-\mathrm{P}(1) & 118.7(2) & \mathrm{C}(22)-\mathrm{C}(23)-\mathrm{C}(24) & 121.1(3) \\ \mathrm{C}(6)-\mathrm{C}(5)-\mathrm{P}(1) & 113.9(2) & \mathrm{C}(19)-\mathrm{C}(24)-\mathrm{C}(23) & 122.2(3) \\ \mathrm{C}(8)-\mathrm{C}(7)-\mathrm{P}(2) & 112.9(2) & \mathrm{C}\left(27^{\prime}\right)-\mathrm{C}(26)-\mathrm{C}\left(27^{\prime}\right) \# 1 & 180.000(3) \\ \mathrm{C}(10)-\mathrm{C}(9)-\mathrm{P}(2) & 117.4(2) & \mathrm{C}\left(27^{\prime}\right)-\mathrm{C}(26)-\mathrm{C}(27) & 53.4(5) \\ \mathrm{C}(12)-\mathrm{C}(11)-\mathrm{P}(2) & 113.0(2) & \mathrm{C}\left(27^{\prime}\right) \# 1-\mathrm{C}(26)-\mathrm{C}(27) & 126.6(5) \\ \mathrm{C}(14)-\mathrm{C}(13)-\mathrm{P}(3) & 114.1(2) & \mathrm{C}\left(27^{\prime}\right)-\mathrm{C}(26)-\mathrm{C}(27) \# 1 & 126.6(5) \\ \mathrm{C}(16)-\mathrm{C}(15)-\mathrm{P}(3) & 118.15(19) & \mathrm{C}\left(27^{\prime}\right) \# 1-\mathrm{C}(26)-\mathrm{C}(27) \# 1 & 53.4(5) \\ \mathrm{C}(18)-\mathrm{C}(17)-\mathrm{P}(3) & 114.13(19) & \mathrm{C}(27)-\mathrm{C}(26)-\mathrm{C}(27) \# 1 & 180.0(8) \\ \mathrm{C}(24)-\mathrm{C}(19)-\mathrm{C}(20) & 115.8(3) & \mathrm{C}(28)-\mathrm{C}(27)-\mathrm{C}(26) & 131.4(9) \\ \mathrm{C}(24)-\mathrm{C}(19)-\mathrm{B}(1) & 122.4(2) & \mathrm{C}(26)-\mathrm{C}\left(27^{\prime}\right)-\mathrm{C}(28) & 123.6(9) \\ \mathrm{C}(20)-\mathrm{C}(19)-\mathrm{B}(1) & 121.6(2) & \mathrm{C}(27)-\mathrm{C}(28)-\mathrm{C}\left(27^{\prime}\right) & 51.6(6) \\ \mathrm{C}(21)-\mathrm{C}(20)-\mathrm{C}(19) & 121.8(3) & & \end{array}$

Symmetry transformations used to generate equivalent atoms:

$\# 1-\mathrm{x},-\mathrm{y},-\mathrm{z}+1$ 
Table S5. Anisotropic displacement parameters $\left(\AA^{2} \times 10^{3}\right)$ for $\mathbf{3 b}$ (with 0.5 equiv of pentane contained in the crystals). The anisotropic displacement factor exponent takes the form: $-2 \pi^{2}\left[h^{2}\right.$ $\left.a^{* 2} U^{11}+\ldots+2 h k a^{*} b^{*} U^{12}\right]$

$$
\begin{array}{llllll}
\mathrm{U}^{11} & \mathrm{U}^{22} & \mathrm{U}^{33} & \mathrm{U}^{23} & \mathrm{U}^{13} & \mathrm{U}^{12}
\end{array}
$$

\begin{tabular}{|c|c|c|c|c|c|c|}
\hline $\operatorname{Rh}(1)$ & $31(1)$ & $22(1)$ & $28(1)$ & 1(1) & $11(1)$ & $5(1)$ \\
\hline $\mathrm{P}(1)$ & $38(1)$ & $32(1)$ & $32(1)$ & $4(1)$ & $15(1)$ & $7(1)$ \\
\hline $\mathrm{P}(2)$ & $37(1)$ & $26(1)$ & $35(1)$ & $2(1)$ & $17(1)$ & $5(1)$ \\
\hline $\mathrm{P}(3)$ & $39(1)$ & $25(1)$ & $32(1)$ & 1(1) & $12(1)$ & $7(1)$ \\
\hline $\mathrm{O}(1)$ & $41(1)$ & $22(1)$ & $39(1)$ & $3(1)$ & $16(1)$ & $5(1)$ \\
\hline $\mathrm{O}(2)$ & $54(1)$ & $26(1)$ & $54(1)$ & $5(1)$ & $17(1)$ & $5(1)$ \\
\hline $\mathrm{B}(1)$ & $45(2)$ & $28(2)$ & $38(2)$ & $2(1)$ & $27(2)$ & $6(1)$ \\
\hline$C(1)$ & $47(2)$ & $48(2)$ & $32(2)$ & $4(1)$ & $15(1)$ & $7(1)$ \\
\hline$C(2)$ & $49(2)$ & $77(2)$ & $43(2)$ & $-14(2)$ & $8(2)$ & $-12(2)$ \\
\hline$C(3)$ & $87(2)$ & $48(2)$ & $48(2)$ & $7(2)$ & $39(2)$ & $21(2)$ \\
\hline $\mathrm{C}(4)$ & $81(2)$ & $62(2)$ & $46(2)$ & $4(2)$ & $36(2)$ & $14(2)$ \\
\hline$C(5)$ & $46(2)$ & $55(2)$ & $44(2)$ & $4(1)$ & $23(1)$ & $-1(1)$ \\
\hline$C(6)$ & $40(2)$ & $121(3)$ & $55(2)$ & $8(2)$ & $13(2)$ & $-6(2)$ \\
\hline$C(7)$ & $46(2)$ & $39(2)$ & $53(2)$ & $4(1)$ & $26(2)$ & $1(1)$ \\
\hline $\mathrm{C}(8)$ & $41(2)$ & $57(2)$ & $76(2)$ & $8(2)$ & $10(2)$ & $-4(1)$ \\
\hline $\mathrm{C}(9)$ & $51(2)$ & $36(2)$ & $45(2)$ & $5(1)$ & $25(1)$ & $11(1)$ \\
\hline$C(10)$ & $90(3)$ & $47(2)$ & $84(3)$ & $11(2)$ & $62(2)$ & $26(2)$ \\
\hline $\mathrm{C}(11)$ & $54(2)$ & $32(1)$ & $36(2)$ & $3(1)$ & $22(1)$ & $9(1)$ \\
\hline $\mathrm{C}(12)$ & $63(2)$ & $51(2)$ & $46(2)$ & $-1(2)$ & $5(2)$ & $6(2)$ \\
\hline$C(13)$ & $65(2)$ & $31(1)$ & $40(2)$ & $-4(1)$ & $18(2)$ & $3(1)$ \\
\hline$C(14)$ & $68(2)$ & $44(2)$ & $82(3)$ & $-18(2)$ & $6(2)$ & $-5(2)$ \\
\hline$C(15)$ & $52(2)$ & $31(1)$ & $36(2)$ & $5(1)$ & $15(1)$ & $11(1)$ \\
\hline$C(16)$ & $97(3)$ & $39(2)$ & $60(2)$ & $16(2)$ & $38(2)$ & $27(2)$ \\
\hline $\mathrm{C}(17)$ & $47(2)$ & $43(2)$ & $39(2)$ & $5(1)$ & $17(1)$ & $20(1)$ \\
\hline$C(18)$ & $43(2)$ & $73(2)$ & $53(2)$ & $5(2)$ & $8(2)$ & $14(2)$ \\
\hline$C(19)$ & $44(2)$ & $31(1)$ & $44(2)$ & $-2(1)$ & $26(1)$ & $0(1)$ \\
\hline$C(20)$ & $55(2)$ & $37(2)$ & $55(2)$ & $-7(1)$ & $30(2)$ & $-4(1)$ \\
\hline$C(21)$ & $49(2)$ & $51(2)$ & $60(2)$ & $-21(2)$ & $30(2)$ & $-17(2)$ \\
\hline$C(22)$ & $41(2)$ & $71(2)$ & $52(2)$ & $-20(2)$ & $20(2)$ & $-9(2)$ \\
\hline$C(23)$ & $50(2)$ & $56(2)$ & $60(2)$ & $-7(2)$ & $8(2)$ & $7(2)$ \\
\hline
\end{tabular}




\begin{tabular}{lcccccc}
$\mathrm{C}(24)$ & $43(2)$ & $39(2)$ & $51(2)$ & $-6(1)$ & $10(1)$ & $-1(1)$ \\
$\mathrm{C}(25)$ & $54(2)$ & $107(3)$ & $74(3)$ & $-34(2)$ & $9(2)$ & $-9(2)$ \\
$\mathrm{C}(26)$ & $61(4)$ & $164(9)$ & $222(12)$ & $-166(9)$ & $81(7)$ & $-48(5)$ \\
$\mathrm{C}(27)$ & $149(8)$ & $132(8)$ & $112(7)$ & $8(6)$ & $80(7)$ & $74(6)$ \\
$\mathrm{C}\left(27^{\prime}\right)$ & $25(5)$ & $43(5)$ & $39(6)$ & $-3(5)$ & $20(5)$ & $1(4)$ \\
$\mathrm{C}(28)$ & $84(3)$ & $117(5)$ & $183(7)$ & $-78(5)$ & $52(4)$ & $-11(3)$ \\
\hline
\end{tabular}


Table 6. Hydrogen coordinates $\left(\mathrm{x} 10^{4}\right)$ and isotropic displacement parameters $\left(\AA^{2} \times 10^{3}\right)$ for $\mathbf{3 b}$ (with 0.5 equiv of pentane contained in the crystals).

\begin{tabular}{|c|c|c|c|c|}
\hline- & $\mathrm{x}$ & $\mathrm{y}$ & $\mathrm{z}$ & $\mathrm{U}(\mathrm{eq})$ \\
\hline $\mathrm{H}(2)$ & $5450(30)$ & $5628(16)$ & $5065(17)$ & $58(10)$ \\
\hline $\mathrm{H}(1 \mathrm{~A})$ & 5636 & 4147 & 4025 & 50 \\
\hline $\mathrm{H}(1 \mathrm{~B})$ & 6170 & 3751 & 3404 & 50 \\
\hline $\mathrm{H}(2 \mathrm{~A})$ & 4005 & 3369 & 3258 & 86 \\
\hline $\mathrm{H}(2 \mathrm{~B})$ & 4391 & 3034 & 4079 & 86 \\
\hline $\mathrm{H}(2 \mathrm{C})$ & 4934 & 2631 & 3464 & 86 \\
\hline $\mathrm{H}(3 \mathrm{~A})$ & 8504 & 2203 & 4371 & 68 \\
\hline $\mathrm{H}(3 \mathrm{~B})$ & 7012 & 2070 & 3937 & 68 \\
\hline $\mathrm{H}(4 \mathrm{~A})$ & 8269 & 2159 & 3122 & 89 \\
\hline $\mathrm{H}(4 \mathrm{~B})$ & 8735 & 3006 & 3417 & 89 \\
\hline $\mathrm{H}(4 \mathrm{C})$ & 7242 & 2853 & 2979 & 89 \\
\hline $\mathrm{H}(5 \mathrm{~A})$ & 8503 & 4095 & 4068 & 56 \\
\hline $\mathrm{H}(5 \mathrm{~B})$ & 8281 & 4455 & 4801 & 56 \\
\hline $\mathrm{H}(6 \mathrm{~A})$ & 10504 & 4141 & 5002 & 108 \\
\hline $\mathrm{H}(6 \mathrm{~B})$ & 10128 & 3259 & 4795 & 108 \\
\hline $\mathrm{H}(6 \mathrm{C})$ & 9907 & 3623 & 5528 & 108 \\
\hline $\mathrm{H}(7 \mathrm{~A})$ & 4230 & 2036 & 6295 & 52 \\
\hline $\mathrm{H}(7 \mathrm{~B})$ & 3551 & 2657 & 6693 & 52 \\
\hline $\mathrm{H}(8 \mathrm{~A})$ & 2250 & 2457 & 5477 & 89 \\
\hline $\mathrm{H}(8 \mathrm{~B})$ & 3436 & 2701 & 5164 & 89 \\
\hline $\mathrm{H}(8 \mathrm{C})$ & 2766 & 3328 & 5560 & 89 \\
\hline $\mathrm{H}(9 \mathrm{~A})$ & 5565 & 4513 & 6736 & 50 \\
\hline $\mathrm{H}(9 \mathrm{~B})$ & 4343 & 4319 & 6052 & 50 \\
\hline $\mathrm{H}(10 \mathrm{~A})$ & 3635 & 4811 & 7031 & 99 \\
\hline $\mathrm{H}(10 \mathrm{~B})$ & 4360 & 4127 & 7556 & 99 \\
\hline $\mathrm{H}(10 \mathrm{C})$ & 3132 & 3942 & 6867 & 99 \\
\hline $\mathrm{H}(11 \mathrm{~A})$ & 5517 & 3105 & 7760 & 47 \\
\hline $\mathrm{H}(11 \mathrm{~B})$ & 6289 & 2390 & 7551 & 47 \\
\hline $\mathrm{H}(12 \mathrm{~A})$ & 7760 & 3218 & 8361 & 83 \\
\hline $\mathrm{H}(12 \mathrm{~B})$ & 7306 & 3921 & 7798 & 83 \\
\hline $\mathrm{H}(12 \mathrm{C})$ & 8079 & 3209 & 7583 & 83 \\
\hline
\end{tabular}




\begin{tabular}{|c|c|c|c|c|}
\hline $\mathrm{H}(13 \mathrm{~A})$ & 6623 & 1303 & 4658 & 53 \\
\hline $\mathrm{H}(13 \mathrm{~B})$ & 6822 & 659 & 5284 & 53 \\
\hline $\mathrm{H}(14 \mathrm{~A})$ & 4607 & 723 & 4606 & 101 \\
\hline $\mathrm{H}(14 \mathrm{~B})$ & 4556 & 1614 & 4816 & 101 \\
\hline $\mathrm{H}(14 \mathrm{C})$ & 4755 & 967 & 5441 & 101 \\
\hline $\mathrm{H}(15 \mathrm{~A})$ & 7576 & 1715 & 7101 & 47 \\
\hline $\mathrm{H}(15 \mathrm{~B})$ & 6168 & 1401 & 6669 & 47 \\
\hline $\mathrm{H}(16 \mathrm{~A})$ & 7476 & 375 & 7276 & 93 \\
\hline $\mathrm{H}(16 \mathrm{~B})$ & 8529 & 548 & 6840 & 93 \\
\hline $\mathrm{H}(16 \mathrm{C})$ & 7115 & 233 & 6405 & 93 \\
\hline $\mathrm{H}(17 \mathrm{~A})$ & 9107 & 1148 & 5936 & 51 \\
\hline $\mathrm{H}(17 \mathrm{~B})$ & 9140 & 1900 & 5454 & 51 \\
\hline $\mathrm{H}(18 \mathrm{~A})$ & 10792 & 1971 & 6576 & 86 \\
\hline $\mathrm{H}(18 \mathrm{~B})$ & 9731 & 1901 & 7024 & 86 \\
\hline $\mathrm{H}(18 \mathrm{C})$ & 9768 & 2653 & 6540 & 86 \\
\hline $\mathrm{H}(20 \mathrm{~A})$ & 8309 & 6171 & 6335 & 55 \\
\hline $\mathrm{H}(21 \mathrm{~A})$ & 10201 & 6264 & 7292 & 61 \\
\hline $\mathrm{H}(23 \mathrm{~A})$ & 10452 & 3957 & 7411 & 68 \\
\hline $\mathrm{H}(24 \mathrm{~A})$ & 8541 & 3857 & 6463 & 54 \\
\hline $\mathrm{H}(25 \mathrm{~A})$ & 12031 & 5724 & 8167 & 120 \\
\hline $\mathrm{H}(25 \mathrm{~B})$ & 12430 & 4865 & 8011 & 120 \\
\hline $\mathrm{H}(25 \mathrm{C})$ & 11550 & 5008 & 8557 & 120 \\
\hline $\mathrm{H}(26 \mathrm{~A})$ & -36 & -357 & 4607 & 169 \\
\hline $\mathrm{H}(26 \mathrm{~B})$ & -837 & 247 & 4883 & 169 \\
\hline $\mathrm{H}(27 \mathrm{~A})$ & 1018 & 1007 & 5331 & 147 \\
\hline $\mathrm{H}(27 \mathrm{~B})$ & 1845 & 386 & 5051 & 147 \\
\hline $\mathrm{H}(27 \mathrm{E})$ & -924 & 657 & 4311 & 40 \\
\hline $\mathrm{H}(27 \mathrm{~F})$ & -84 & 33 & 4035 & 40 \\
\hline $\mathrm{H}(28 \mathrm{~A})$ & 1772 & 1405 & 4546 & 188 \\
\hline $\mathrm{H}(28 \mathrm{~B})$ & 214 & 1381 & 4264 & 188 \\
\hline $\mathrm{H}(28 \mathrm{C})$ & 1053 & 750 & 3980 & 188 \\
\hline
\end{tabular}




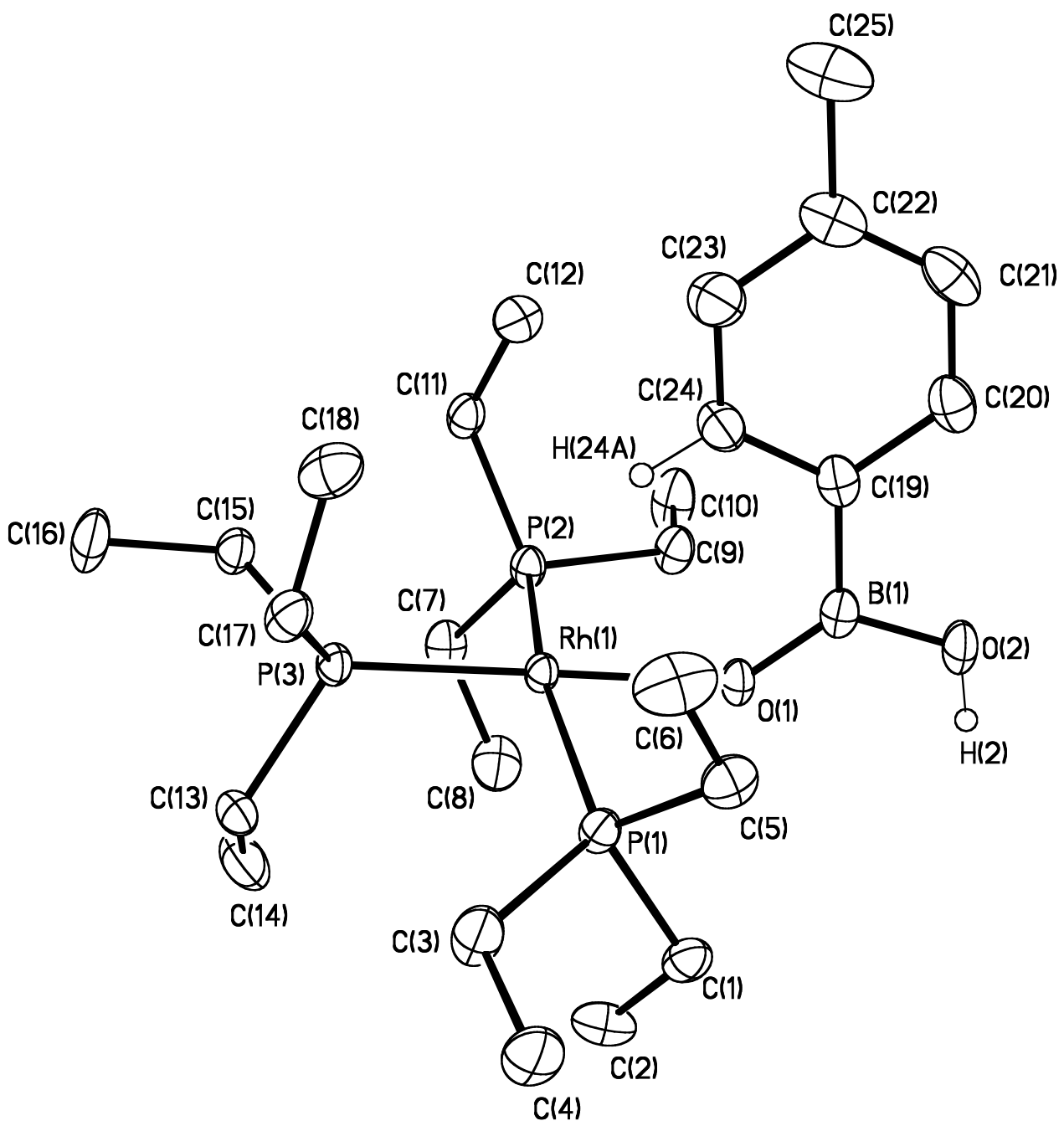

Figure S8. ORTEP diagram of $\left[\left(\mathrm{PEt}_{3}\right)_{3} \mathrm{RhOB}(\mathrm{OH})(p\right.$-tolyl) $](\mathbf{3 b})$. 